\title{
PENGARUH DANA PERIMBANGAN TERHADAP KEMANDIRIAN KEUANGAN DAERAH
}

\author{
Ari Mulianta Ginting \\ Pusat Penelitian, Setjen dan Badan Keahlian DPR RI \\ Muhammad Zilal Hamzah \\ STIE Bisnis Indonesia \\ Eleonora Sofilda \\ Universitas Trisakti
}

Alamat Korespondensi: ari.ginting@dpr.go.id

\begin{abstract}
Indonesia entered a new era from centralized to decentralized. The impact of decentralization is the existence of fiscal decentralization to provide balanced funds to carry out their duties and responsibilities. However, the provision of the fiscal decentralization has another impact, namely the involvement of the regional government to the fiscal decentralization. The study used quantitative method analysis with a model data panel regression approach using data from district/city clusters from clusters I to IV from 2013-2018. The study also used quadrant analysis to map districts/cities to fiscal decentralization and local government financial independence. The results of panel regression analysis found that the effect of fiscal decentralization had a positive and significant effect on local government financial independence only in cluster II, while other clusters did not have a significant effect on local government financial independence. The results of the panel regression analysis are in line with quadrant analysis that from the district/city data in both I-IV clusters, almost 91.3 percent of the districts/cities are in quadrant IV. These results indicate that on average 91.3 percent of districts/cities have relatively low fiscal decentralization with local government financial independence which are also relatively low for clusters I, III and IV. Based on these results, the district/city government must allocate a budget to the potential that can be used as a source of revenue for the local government, especially for investment and productive expenditure.
\end{abstract}

\section{KATA KUNCI:}

Dana Perimbangan, Kemandirian Keuangan Pemerintah Daerah, Analisa Regresi Panel Data

\begin{abstract}
ABSTRAK
Indonesia memasuki era baru dari sentralistik menjadi desentralistik. Dampak dari desentralisasi tersebut adalah adanya pemberian dana perimbangan untuk melaksanakan tugas dan tanggung jawab. Namun pemberian dana perimbangan tersebut, memberikan dampak lain yaitu ketergantungan pemerintah daerah kepada dana perimbangan. Penelitian ini menggunakan analisis metode kuantitatif dengan pendekatan regresi panel data model dan menggunakan data dari kluster kabupaten/kota dari kluster I sampai dengan IV pada tahun 2013-2018. Penelitian ini juga menggunakan analisis kuadran untuk melakukan mapping terhadap kabupaten/kota terhadap dana perimbangan dan kemandirian keuangan daerah. Hasil analisa regresi panel ditemukan bahwa dana perimbangan memiliki pengaruh yang positif dan signifikan terhadap kemandirian keuangan daerah hanya di kluster II, sedangkan kluster lainnya tidak memiliki pengaruh yang signifikan terhadap kemandirian keuangan daerah. Hasil analisa regresi panel ini sejalan dengan analisa kuadran bahwa dari data kabupaten/kota yang ada baik di kluster I-IV, hampir 91,3 persen kabupaten/kota yang ada berada di kuadran IV. Hasil ini menunjukkan bahwa secara rata-rata 91,3 persen kabupaten/kota memiliki dana perimbangan yang realtif rendah dengan kemandirian keuangan yang juga relatif rendah untuk kluster I, III dan IV. Berdasarkan hasil tersebut maka pemerintah daerah kabupaten/kota harus mengalokasikan anggaran kepada potensi yang dapat dijadikan sebagai sumber penerimaan bagi daerah khususnya kepada belanja yang bersifat investasi dan produktif.
\end{abstract}

KLASIFIKASI JEL:

E62, R51, C23

CARA MENGUTIP:

Ginting, A. M., Hamzah, M. Z, \& Sofilda, E. (2019). Pengaruh dana perimbangan terhadap kemandirian keuangan daerah. Indonesian Treasury Review, 4(2), 105-127. 


\section{PENDAHULUAN}

\subsection{Latar Belakang}

Sejarah desentralisasi yang dialami oleh bangsa Indonesia mengalami fluktuasi. Sejarah tersebut dimulai dari era Orde Lama, Orde Baru hingga sekarang Orde Pasca Reformasi. Upaya sentralistik yang dilakukan pada era pemerintahan Orde Baru selama kurang lebih 33 tahun yang pada awal dianggap sukses, namun pada akhirnya kurang berhasil membawa kemakmuran dan kemajuan bagi bangsa dan negara terutama bagi pemerintahan daerah. Pemerintah daerah seakan berjalan ditempat tanpa ada perubahan berarti bagi kesejahteraan masyarakat di daerah (Wasistiono, Sadu \& Polyando, 2017).

Ketidakpuasan pemerintahan daerah akibat kebijakan pemerintahan yang sentralistik mendorong banyak pemerintahan daerah mendorong kebijakan desentralisasi. Tuntutan terhadap otonomi yang lebih luas mengemuka di hampir seluruh Indonesia hingga pada akhirnya pada periode setelah Reformasi berhasil dikeluarkan kebijakan otonomi daerah yang disertai dengan desentralisasi fiskal kepada pemerintahan daerah (Kuncoro, 2014). Hal tersebut terwujud dengan dikeluarkannya Undang-Undang No. 22 Tahun 1999 tentang Pemerintahan Daerah dan Undang-Undang No. 25 Tahun 1999 tentang Perimbangan Keuangan antara Pusat dan Daerah. Undang-Undang inilah yang menjadi pendorong dan cikal bakal otonomi, desentralisasi dengan memberikan penyerahan akan kewajiban dan hak bagi pemerintahan daerah.
Lebih lanjut dalam revisi Undang-Undang No. 22 Tahun 1999 yang menjadi Undang-Undang No. 23 Tahun 2014 tetang Pemerintahan Daerah menegaskan tentang landasan yang menjadi latar belakang mengenai hubungan antara Pemerintah Pusat dan pemerintahan daerah. Bagian penjelasan dalam UU No. 23 Tahun 2014 dijelaskan bahwa pemberian otonomi daerah kepada pemerintahan daerah yang luas ditujukan untuk mendorong terciptanya kesejahteraan masyarakat melalui peningkatan kuantitas dari pelayanan, pemberdayaan dan peran serta mendorong kemandirian dan meningkatan perekonomian daerah.

Salah satu dampak dari desentralisasi fiskal tersebut menurut Simanjuntak \& Mukhlis (2016) bahwa pemberian dana perimbangan adalah meningkatkan kapasitas fiskal pemerintahan daerah. Penelitian tersebut menyebutkan bahwa dengan menggunakan metode analisis Partial Least Square (PLS) dan sampel data yang digunakan menggunakan Provinsi Jawa Timur menunjukkan hasil bahwa penerapan dana perimbangan memiliki pengaruh yang positif dan signifikant terhadap kapasitas fiskal. Peningkatan kapasitas fiskal tersebut mendorong peningkatan kapasitas dan kemandirian keuangan dari pemerintah daerah. Hal ini sejalan dengan penelitian yang dilakukan oleh Fafurida \& Pratiwi (2017) dan Suprantiningrum (2015) yang juga menemukan bahwa dana perimbangan memberikan pengaruh yang positif dan signifikan terhadap peningkatan tingkat kemandirian keuangan dari pemerintah daerah.

Gambar 1. Perkembangan PAD dan Dana Perimbangan Periode tahun 2013-2018 secara Agregat seluruh Kabupaten/Kota di Indonesia

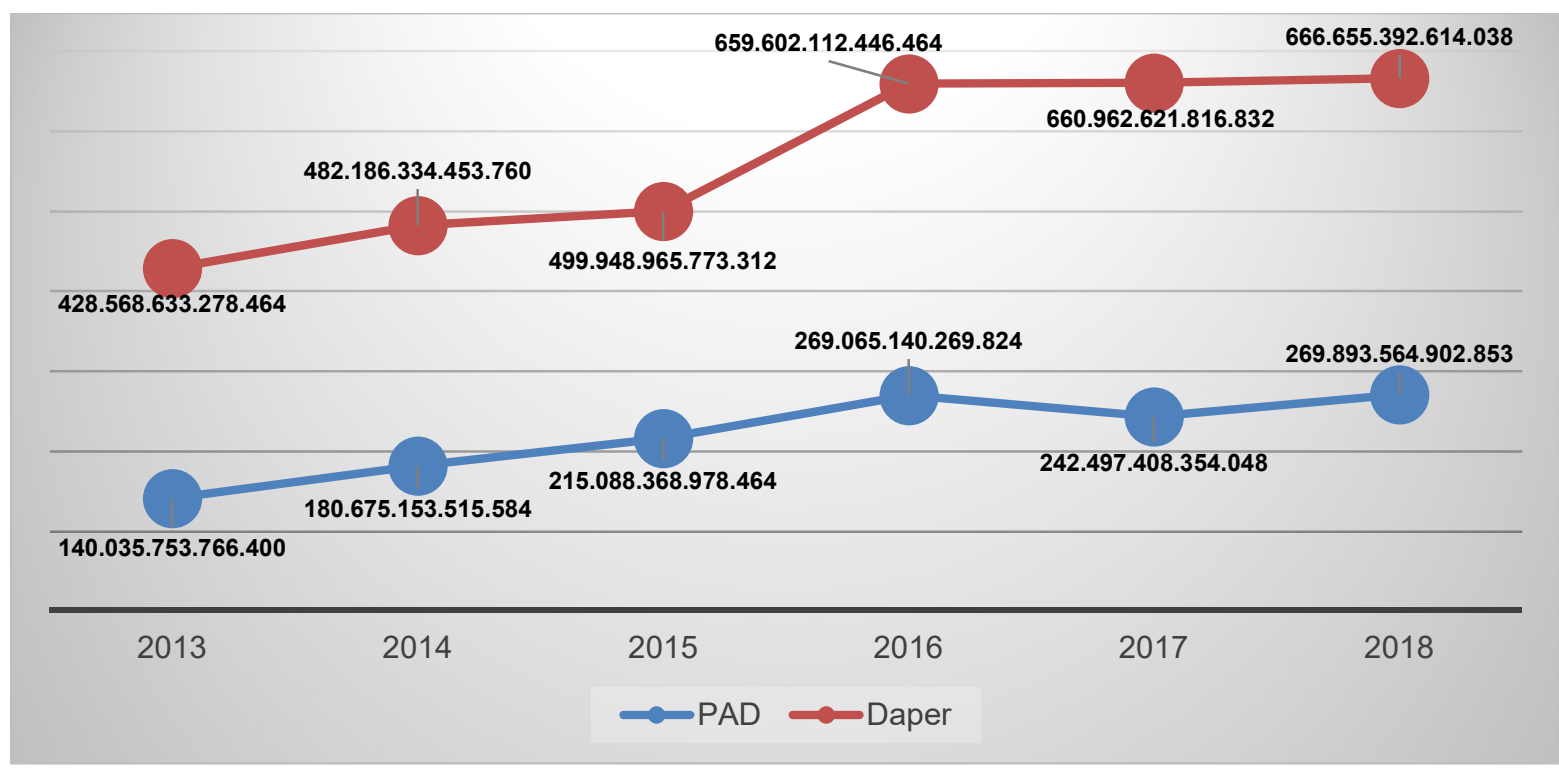

Sumber: Data Diolah (2019). 
Namun dalam perkembangannya dana perimbangan menimbulkan beberapa dampak terhadap pemerintah daerah. Salah satu kendala yang muncul adalah ketergantungan pemerintah daerah akan dana perimbangan yang setiap tahun dianggarkan kepada pemerintah daerah. Hal ini berdampak bahwa pemberian dana perimbangan kurang memberikan stimulus bagi pemerintah daerah untuk meningkatkan kemandirian keuangan melalui peningkatan penerimaan asli daerah (PAD) (Ginting, 2018). Gambar 1 memberikan penjelasan bahwa dari periode tahun 2013 sampai dengan tahun 2018 perkembangan PAD secara agregat seluruh kabupaten/kota di Indonesia selalu lebih rendah jika dibandingkan dengan dana perimbangan yang diberikan Pemerintah Pusat. Data menunjukkan bahwa tren peningkatan PAD per tahun rata-rata meningkat kurang lebih 14,93 persen per tahun, pada saat yang bersamaan terjadi peningkatan dana perimbangan dari tahun $2013 \mathrm{ke}$ tahun 2018 meningkat 53,04 persen. Hal ini menunjukkan bahwa pemerintah daerah semakin lama semakin bergantung kepada dana perimbangan yang diberikan oleh Pemerintah Pusat (Haryanto, 2015).

\subsection{Tujuan dan Kerangka Pemikiran}

Berdasarkan uraian sebelumnya, maka penelitian ini bertujuan untuk menganalisis penaruh dana perimbangan terhadap perekonomian daerah. Fokus dari penelitian ini adalah sebagai berikut:

1. Menganalisis pengaruh dana perimbangan terhadap kemandirian keuangan daerah.

2. Memetakan variabel kemandirian keuangan daerah dan dana perimbangan.

3. Memberikan masukan rekomendasi kebijakan terhadap kebijakan desentralisasi di Indonesia.

Penelitian ini mencoba membatasi ruang lingkupnya dengan membatasi periode penelitian yaitu tahun 2013 sampai dengan tahun 2018. Kemudian penelitian ini juga mengeluarkan data kabupaten/kota dari Provinsi Daerah Khusus Ibu Kota Jakarta dalam pengamatan atau objek penelitian. Kerangka pemikiran studi ini diorganisasikan sebagaimana ditunjukkan pada Gambar 2.

Gambar 2. Kerangka Pemikiran Pengaruh Dana Perimbangan terhadap Kemandirian Keuangan Daerah

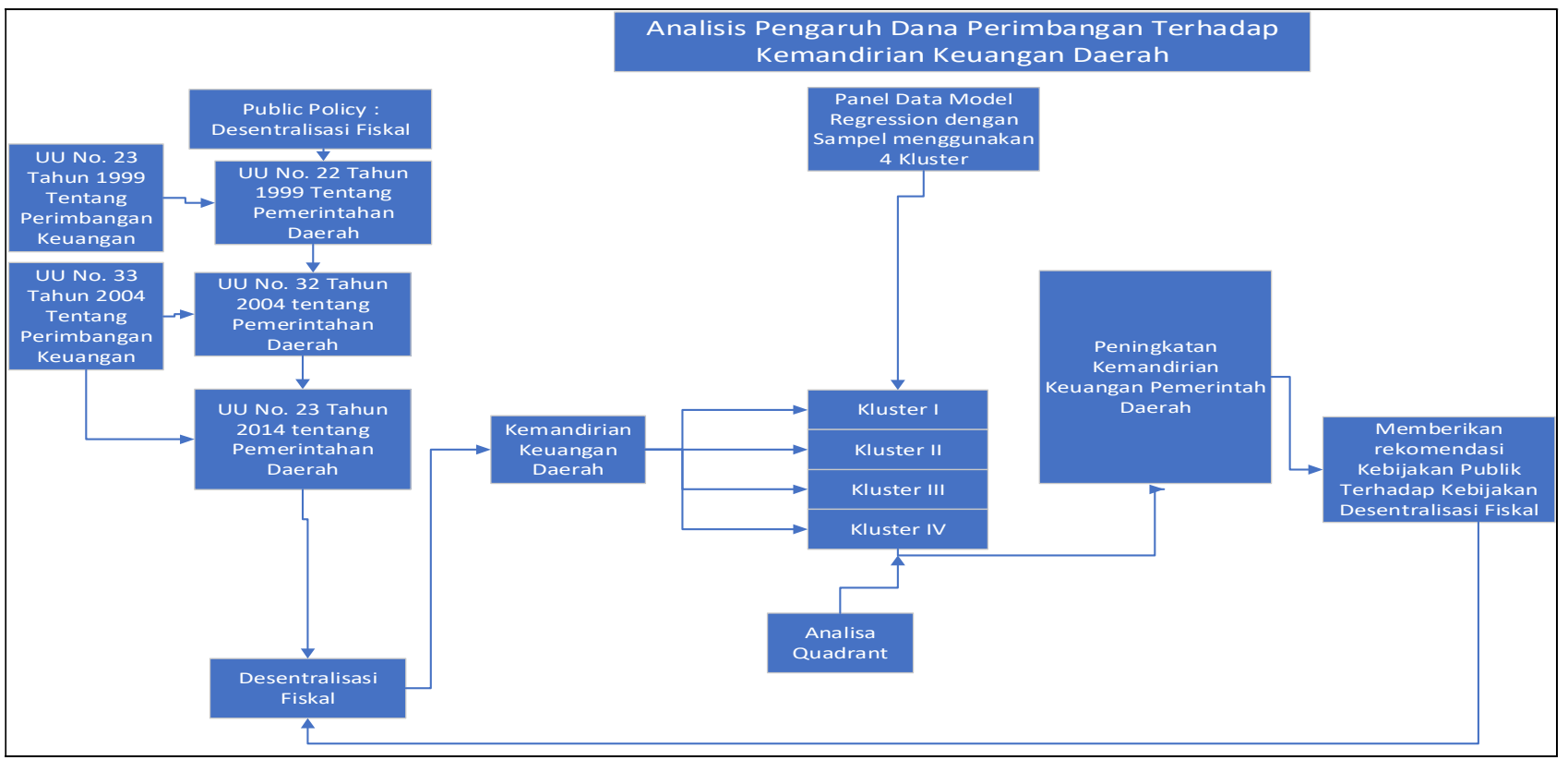

Berdasarkan pengorganisasian kerangka pemikiran tersebut, studi ini mencoba menjawab pertanyaan penelitian: bagaimana pengaruh dana perimbangan terhadap kemandirian keuangan daerah, bagaimana hasil analisis kuadran terhadap variabel kemandirian keuangan dan dana perimbangan serta memberikan rekomendasi kebijakan terkait kebijakan desentralisasi dan otonomi di Indonesia.

\section{Kerangka Teori \\ 2.1. Dana Perimbangan (fiscal decentralization)}

Ghuman \& Singh (2013) mendefinisikan desentralisasi fiskal sebagai transfer kekuatan, kekuasaan, dan tanggung jawab dari Pemerintah Pusat kepada pemerintah yang lebih rendah. Teori desentralisasi berawal dari konsep yang dikembangkan oleh Tiebout Hypotesis pada tahun 1956. Tiebout menyebutkan bahwa pemerintah yang lebih rendah menawarkan barang dan jasa untuk memenuhi kebutuhan hidup masyarakat 
sebagai pengganti pajak. Dengan konsep tersebut maka pemerintah daerah memberikan pelayanan publik terhadap masyarakat yang ada di daerah pemerintah daerah. Dengan cara ini, pemerintah daerah yang heterogen berhasil menyelesaikan berbagai masalah inefisiensi penyediaan layanan publik lokal (Michael, 2008).

Oates (1972) mengemukakan teori desentralisasi bahwa pelayanan publik harus disediakan oleh pemerintah daerah setempat yang dekat dengan masyarkat. Hal ini dikarenakan beberapa alasan utama mendasar yaitu:

a. Pemerintah daerah dianggap paling mengerti akan masyarakat setempat;

b. Keputusan yang dilakukan oleh pemerintah daerah terkait dengan pelayanan publik dianggap lebih efesien dan cepat jika dilakukan desentralisasi;

c. Dapat menghilangkan sekat-sekat penghalang keputusan dalam pengambilan keputusan terkait pelayanan publik;

d. Dapat meningkatkan inovasi persaingan pelayanan publik antar pemerintah daerah.

Desentralisasi kepada pemerintah yang lebih rendah juga memberikan keunggulan lainnya, antara lain adalah keunggulan informasi, peningkatan efesiensi dalam penyediaan pelayanan publik. Hal ini dikarenakan pemerintah daerah lebih dekat kepada kepada masyarakat di daerah sehingga lebih mampu menyediakan kebutuhan masyarakat di daerah dan dapat mendorong pertumbuhan ekonomi daerah. Hasil akhirnya adalah peningkatan kesejahteraan masyarakat di daerah (Jin \& Zou, (2005), Zhang et al., (2014), DiazSerrano \& Rodríguez-Pose, (2015), Khamdana, (2016)).

Undang-Undang No 22 tahun 1999 tentang Pemerintahan Daerah yang kemudian diubah menjadi Undang-Undang No 23 tahun 2014 tentang Pemerintahan Daerah menjelaskan konsep otonomi dan desentralisasi secara jelas. Otonomi daerah dijelaskan sebagai hak, wewenang, dan kewajiban daerah otonom untuk mengatur dan mengurus sendiri urusan pemerintahan dan kepentingan masyarakat setempat dalam sistem Negara Kesatuan Republik Indonesia. Dalam pelaksanaan otonomi daerah konsep utama adalah pemberian desentralisasi, yaitu penyerahan urusan pemerintahan pusat kepada pemerintah daerah dan disertai dengan pemberian dana perimbangan (fiscal decentralization) kepada pemerintah daerah untuk melaksanakan tugas tersebut (UndangUndang No. 23 Tahun 2014).

Konsep desentralisasi fiskal merupakan suatu konsep desentralisasi baik di dalam bentuk politik, fiskal, administratif, dan ekonomi. Dari keempat bentuk desentralisasi seperti yang diuraikan sebelumnya, bentuk desentralisasi yang sudah dijalankan dan diterapkan di Indonesia adalah diantaranya desentralisasi dalam bentuk politik, administrasi, dan fiskal. Otonomi daerah yang telah berlangsung sejak tahun $2001 \mathrm{di}$ Indonesia mengalami perkembangan yang luar biasa. Perubahan pola kewenangan dan kekuasaan yang terpusat secara perlahan didelegasikan kepada daerah terdapat perubahan pola pendekatan dari sentralistik berubah menjadi desentralistik. Desentralisasi sendiri menurut Dwipayana (2003) memberikan pendapat bahwa berlangsungnya perubahan mendasar yang menjadi karateristik hubungan kekuasaan daerah dengan pusat, sehingga pemerintah daerah dapat diberikan kekuasaan untuk menghasilkan keputusan politik tanpa adanya campur tangan Pemerintah Pusat.

Secara konsep, desentralisasi fiskal itu sendiri didefinisikan sebagai memberikan wewenang kepada pemerintah daerah untuk mengeksplorasi sumber pendapatan daerah, hak untuk menerima dana desentralisasi yang berasal dari pemerintah yang lebih tinggi dan menentukan sendiri secara mandiri terhadap belanja dan investasi yang akan dikeluarkan oleh pemerintah daerah, serta pemerintah daerah diberikan kesempatan untuk menentukan regulasi terhadap anggaran. Definisi lain dari desentralisasi fiskal adalah sebagai suatu proses penyerahan baik tanggungjawab fiskal kepada pemerintah daerah termasuk di dalamnya ada wewenang untuk mengumpulkan pajak dan pengeluaran dengan pengaturan untuk melakukan koreksi terhadap ketidakseimbangan sumber daya dan kewajiban yang ada (Malik, Shahnawaz; Mahmood-Ul-Hassan; Husain, 2006).

Mardiasmo (2002) menyatakan desentralisasi fiskal memberikan dua dampak nyata. Pertama, desentralisasi fiskal meningkatkan tingkat partisipasi, prakarsa, dan kreatifitas dari masyarakat terkait dengan pembangunan, serta meningkatkan hasil-hasil pembangunan secara merata di seluruh daerah dengan memanfaatkan sumber daya dan protensi yang ada di masyarakat. Kedua, memperbaiki pengalokasian sumber daya yang produktif melalui pergeseran peran dan pengambilan kebijakan publik ke tingkat pemerintahan yang memiliki informasi yang lebih lengkap dibandingkan pemerintah di atasnya.

\subsection{Pengaruh Dana Perimbangan terhadap Kemandirian Keuangan Daerah}

Otonomi daerah yang disertai dengan pemberian dana perimbangan merupakan dampak yang harus diterima akibat dari pelaksanaan otonomi daerah dan desentralisasi sebagai kebijakan yang telah diputuskan oleh Pemerintah bersama Dewan Perwakilan Rakyat Republik Indonesia (DPR RI) dalam Undang-Undang No. 22 Tahun 1999 tentang Pemerintahan Daerah dan 
Undang-Undang No. 23 Tahun 1999 tentang Perimbangan Keuangan antara Pusat dan Daerah. Lebih lanjut dalam penjelasan Undang-Undang No. 23 tahun 2014 tentang Pemerintahan Daerah menyebutkan bahwa pemerintah daerah harus mempunyai sumber keuangan agar daerah tersebut mampu memberikan pelayanan dan meningkatkan kesejahteraan masyarakat. Hal ini berarti bahwa pemberian dana perimbangan kepada pemerintah daerah sudah selayaknya dapat meningkatkan kemampuan pemerintah daerah untuk dapat menggali dan meningkatkan sumber-sumber penerimaan daerah untuk dapat membiayai pelayanan publik dan meningkatkan kesejahteraan masyarakat.

Sejalan dengan hal tersebut maka salah satu variabel yang digunakan untuk menganalisis kemampuan dan kemandirian keuangan daerah tersebut adalah dengan menggunakan suatu rasio. Rasio tersebut adalah rasio kemandirian keuangan daerah, yaitu rasio yang menghitung dengan cara membandingkan antara pendapatan asli daerah dibagi dengan total dana perimbangan daerah (Halim, 2004). Desentralisasi fiskal diharapkan dapat meningkatkan kemandirian keuangan pemerintah daerah untuk menstimulus daerah menggali sumber-sumber penerimaan daerah. Namun pada kenyataannya pemberian dana desentralisasi fiskal belum dapat memberikan perbaikan signifikan terhadap kemandirian keuangan daerah. Kondisi ini diperparah dengan masih banyaknya pemerintah daerah yang masih sangat bergantung kepada dana perimbangan fiskal yang diberikan Pemerintah Pusat (Solihin \& Lesatri, 2010).

Lebih lanjut mengenai rasio kemandirian keuangan daerah, Paul Hersey dan Kenenth Blanard dalam Halim (2004) melakukan klasifikasi tingkat kemandirian keuangan daerah seperti yang terlihat pada tabel 1 . Tabel 1 menunjukkan rasio kemandirian keuangan daerah semakin tinggi berarti semakin rendah ketergantungan pemerintah daerah terhadap pihak eksternal dan sebaliknya. Rasio kemandirian keuangan daerah juga mendeskripsikan tingkat partisipasi masyarakat di daerah dalam menyokong pembangunan daerah. Semakin tinggi rasio tersebut maka semakin tinggi pula tingkat partisipasi masyarkat di daerah untuk membayar pajak dan retribusi daerah yang merupakan sumber utama pendapatan asli daerah.

Tabel 1. Tingkat Kemandirian Keuangan

$$
\text { Daerah }
$$

\begin{tabular}{|c|c|}
\hline $\begin{array}{c}\text { Kemampuan } \\
\text { Keuangan Daerah }\end{array}$ & $\begin{array}{c}\text { Kemandirian } \\
\text { Keuangan Daerah (\%) }\end{array}$ \\
\hline Rendah Sekali & $0,00-25 \%$ \\
\hline Rendah & $25 \%-50 \%$ \\
\hline Sedang & $50 \%-75 \%$ \\
\hline Tinggi & $75 \%-100 \%$ \\
\hline
\end{tabular}

Sumber: Halim (2014)
Hankla dan Hankla (2009) melakukan penelitian tentang kapan desentralisasi fiskal baik untuk pemerintah daerah. Dalam paper tersebut dijelaskan bahwa desentralisasi fiskal berdampak positif bagi pemerintah daerah jika salah satunya dapat meningkatkan kapasitas pemerintah daerah. Peningkatan kapasitas tersebut dalam berbagai aspek salah satunya adalah kemampuan meningkatkan pendapatan asli daerah sebagai sumber pendanaan keuangan daerah.

Lebih lanjut Kalirajan mengemukakan bahwa desentralisasi fiskal memberikan dampak terhadap pengembangan kapasitas pemerintah daerah terutama untuk meningkatkan penerimaan daerah. Studi yang dilakukan dengan mengambil kasus Negara India, fokus pemberian desentralisasi fiskal terhadap pemerintah daerah ternyata memberikan dampak terhadap peningkatan kapasitas pemerintah daerah melalui belanja yang berkualitas. Peningkatan belanja yang berkualitas tersebut ternyata berujung terhadap peningkatan perekonomian daerah yang muara akhirnya yaitu peningkatan penerimaan asli daerah.

Lebih lanjut pengaruh desentralisasi fiskal terhadap kemandirian keuangan daerah pernah dilakukan oleh beberapa penelitian sebelumnya seperti, Haryanto (2018) dengan menggunakan data dari tahun 2008 hingga tahun 2014, ditemukan bahwa ada peningkatan kemandirian keuangan seiring dengan peningkatan desentralisasi fiskal yang diterima oleh pemerintah daerah. Hasil penelitian ini senada dengan penelitian yang dilakukan oleh (Fafurida \& Pratiwi (2017); (Simanjuntak \& Mukhlis, 2016) yang menemukan peningkatan kemandirian keuangan pemerintah daerah sejalan dengan peningkatan desentralisasi fiskal. Namun penelitian yang dilakukan oleh Ginting (2018) menggunakan data di Kabupaten/Kota di Provinsi Sumatera menunjukkan bahwa desentralisasi fiskal belum dapat mendorong kemandirian keuangan daerah.

\section{METODOLOGI PENELITIAN}

\subsection{Rancangan Penelitian dan Populasi Penelitian}

Rancangan penelitian ini bertujuan untuk menganalisis pengaruh dana perimbangan terhadap kemandirian keuangan daerah. Penelian ini menggunakan populasi data dari kabupaten/kota di Indonesia yang dibagi menjadi 4 kluster data penelitian. Tabel 2 menunjukkan 4 kluster data penelitian yang digunakan dalam penelitian. Data lengkap mengenai kluster data kabupaten/kota yang digunakan dapat dilihat pada bagian lampiran. 
Tabel 2. Kluster Data Penelitian

\begin{tabular}{|c|c|c|}
\hline No. & Kluster & Wilayah \\
\hline 1. & $\begin{array}{c}\text { Daerah yang menerima tambahan dana selain dana } \\
\text { perimbangan, seperti dana otonomi khusus. }\end{array}$ & $\begin{array}{c}\text { Kabupaten/Kota di Provinsi Aceh. } \\
\text { Kabupaten/Kota di Provinsi Daerah Istimewa } \\
\text { Yogyakarta }\end{array}$ \\
$\begin{array}{c}\text { Kabupaten/Kota di Provinsi Papua } \\
\text { Kabupaten/Kota di Provinsi Papua Barat }\end{array}$ \\
\hline 2. & $\begin{array}{c}\text { Daerah yang memiliki proporsi pendapatan asli } \\
\text { daerah (PAD) dibandingkan dengan dana } \\
\text { perimbangan > 50\% }\end{array}$ & $\begin{array}{c}\text { Data lengkap kabupaten/kota di Kluster II dapat } \\
\text { dilihat pdaten bagian Lampiran I }\end{array}$ \\
\hline 3. & $\begin{array}{c}\text { Daerah yang memiliki proporsi pendapatan asli bagian Lampiran I. } \\
\text { daerah (PAD) dibandingkan dengan dana } \\
\text { perimbangan antara 25\% sampai dengan 50\% }\end{array}$ & $\begin{array}{c}\text { Data lengkap kabupaten/kota yang ada di Kluster III } \\
\text { dapat dilihat pada Bagian Lampiran I. }\end{array}$ \\
\hline 4. & $\begin{array}{c}\text { Daerah yang memiliki proporsi pendapatan asli } \\
\text { daerah (PAD) dibandingkan dengan dana } \\
\text { perimbangan kurang dari 25\% }\end{array}$ & $\begin{array}{c}\text { Data lengkap kabupaten/kota yang ada di Kluster IV } \\
\text { dapat dilihat pada Bagian Lampiran I. }\end{array}$ \\
\hline
\end{tabular}

Sumber: Penulis (2019).

Penelitian ini menggunakan data sekunder dengan data panel, yaitu gabungan data dari data dalam bentuk time series dan cross section. Data time series yang digunakan dari tahun 2013 hingga tahun 2018, sedangkan data cross section yang digunakan merupakan data dari kabupaten/kota dari berbagai provinsi yang ada di seluruh Indonesia berdasarkan kluster yang telah ditentukan dalam Tabel 2 . Penggunaan data cross section yang digunakan dalam penelitian ini menggunakan metode kluster terhadap kabupaten dan kota yang ada di provinsi di Indonesia. Pembagian kabupaten dan kota ke dalam 4 kluster seperti yang dapat dilihat pada Tabel 2 di atas.

\subsection{Metode Analisis}

Tahapan selanjutnya adalah data yang telah dikumpulkan melalui serangkaian teknik pengumpulan data, maka tahapan berikutnya adalah analisis data dengan menggunakan metode kualitatif dan kuantitatif. Tahapan pertama adalah melakukan analisis dengan metode kualitatif. Pada tahapan ini terdapat tiga langkah yang dilakukan dalam analisis data kualitatif ini, yaitu reduksi data, penyajian data, serta terakhir penarikan simpulan. Reduksi data dilakukan dengan tujuan agar data yang berasal dari sumber tersebut dapat dipahami. Pada tahapan ini, peneliti melakukan editing dan mengategorisasikan data sesuai dengan masalah dan tujuan yang telah ditetapkan dalam penelitian ini. Langkah selanjutnya adalah menyajikan data dan menarik simpulan. Tahapan berikutnya adalah analisa kuantitatif untuk melihat pengaruh dana perimbangan terhadap perekonomian daerah. Pendekatan kuantitaif yang digunakan adalah menggunakan pendekatan data panel. Pada bagian pembahasan dan analisis akan dibahas secara lengkap dan jelas prosedur dan analisa kuantitatif dengan menggunakan pendekatan regresi panel dan melakukan intrepetasi terhadap hasil tersebut.
Penelitian ini menggunakan data panel model untuk menjawab berbagai masalah yang telah ditetapkan di bagian awal. Data panel merupakan salah satu bentuk metode dalam ekonometrika yang muncul karena adanya keterbatasan metode time series dan cross section. Data panel adalah bentuk data yang menggabungkan dua dimensi yaitu dimensi ruang dan dimensi waktu. Penggabungan kedua jenis data yaitu data cross section dan time series yang digunakan untuk menjawab permasalahan yang tidak dapat diberikan baik oleh model cross section maupun time series. Gujarati (2004) mengatakan bahwa model regresi panel data sebagai pooled data atau dengan bahasa lain merupakan kumpulan dari data time series dan cross section, micropanel data, longitudinal data atau kombinasi studi atas dasar waktu dari berbagai variabel atau kelompok subjek, event history analyisis atau studi perubahan objek dengan syarat tertentu, atau corhot analyisis.

Regresi panel data model terdapat tiga pilihan model estimasi yang dapat dilakukan yaitu common effect, fixed effect, dan random effect. Untuk menentukan salah satu model yang diestimasi yang dianggap paling tepat dari ketiga jenis model tersebut maka dilakukan serangkaian pengujian yaitu Uji Wald, Uji Hausman Test, dan Uji Langrage Multiplier. Uji Wald Test digunakan untuk mengetahui atau memilih ada tidaknya pengaruh efek individu dalam model dengan membandingkan nilai $\mathrm{R}^{2}$ dari nilai model common effect dengan model fixed effect. Sedangkan uji Hausman Test digunakan untuk menentukan pilihan model estimasi antara fixed effect dengan random effect (Ekananda, 2016).

Model yang dipakai dalam penelitian ini adalah untuk menganalisis pengaruh dana desentralisasi terhadap kemandirian keuangan daerah. Model yang dipakai dalam penelitian ini 
menggunakan penelitian yang dilakukan oleh Psycharis, Zoi, \& Iliopoulou (2015), dimana kemandirian keuangan dipengaruhi oleh Jumlah penduduk, dana perimbangan, pertumbuhan ekonomi dan jumlah pengangguran dan sumber daya manusia. Model tersebut adalah:

$$
K K D_{i t}=a_{i t}+b_{i t} P_{o p}+c_{i t} F D_{i t}+d_{i t} E G_{i t}+
$$$$
e_{i t} U N_{i t}+f_{i t} S D M_{i t}+\varepsilon t
$$

KKD : kemandirian keuangan daerah

Pop : jumlah penduduk

FD : dana perimbangan

EG : pertumbuhan ekonomi

UN : tingkat pengangguran

SDM : sumber daya manusia

i $\quad$ : cross section untuk kluster data

kabupaten/kota

t $\quad$ : periode waktu

Setelah dilakukan analisis kuantitatif dengan menggunakan regresi panel data, maka langkah selanjutnya adalah melakukan analisis kuadran terhadap keempat kluster, baik kluster 1 sampai dengan kluster 4 untuk menyandingkan dan memetakan variabel kemandirian keuangan daerah dengan dana perimbangan ke dalam empat kuadran. Metode kuadran tersebut dengan rincian berikut:

a. Kuadran I: yaitu kabupaten/kota yang memiliki karateristik memiliki dana perimbangan yang besar akan tetapi memiliki kemandirian keuangan daerah yang cukup tinggi.

b. Kuadran II: yaitu kabupaten/kota yang memiliki karateristik memiliki dana perimbangan yang besar akan tetapi memiliki kemandirian keuangan daerah yang rendah.

c. Kuadran III: yaitu kabupaten/kota yang memiliki karakteristik memiliki dana perimbangan rendah akan tetapi memiliki kemandirian keuangan daerah yang tinggi.

d. Kuadran IV: yaitu kabupaten/kota yang memiliki karakteristik meliki dana perimbangan yang rendah dan kemandirian keuangan daerah yang juga rendah.

\section{HASIL PENELITIAN}

\subsection{Pengujian Model Pengaruh Dana Perimbangan terhadap Kemandirian Keuangan}

Pada bagian berikut akan dilakukan pengujian terhadap model regresi panel data untuk menentukan Common Effect Model (CEM) atau Fixed Effect Model (FEM) dalam regresi panel data terhadap kluster 1 sampai dengan 4 dengan menggunakan Uji Wald. Langkah selanjutnya adalah melakukan Uji Hausman untuk menentukan apakah model Fixed Effect Model (FEM) atau Random Effect
Model (REM) terhadap kluster data dari 1 sampai dengan 4. Ringkasan hasil pengujian Uji Wald dan Uji Hausman dapat dilihat pada tabel 3 di bawah.

Tabel 3. Hasil Pengujian CEM vs FEM dan FEM vs REM pada Model Pengaruh Dana Perimbangan terhadap Kemandirian Keuangan Daerah

\begin{tabular}{|c|c|c|c|c|}
\hline $\begin{array}{c}\text { Model } \\
\text { Uji }\end{array}$ & Kluster I & $\begin{array}{c}\text { Kluster } \\
\text { II }\end{array}$ & $\begin{array}{c}\text { Kluster } \\
\text { II }\end{array}$ & $\begin{array}{c}\text { Kluster } \\
\text { IV }\end{array}$ \\
\hline $\begin{array}{c}\text { CEM vs } \\
\text { FEM }\end{array}$ & FEM & FEM & FEM & FEM \\
\hline $\begin{array}{c}\text { FEM vs } \\
\text { REM }\end{array}$ & REM & REM & REM & FEM \\
\hline $\begin{array}{c}\text { Hasil } \\
\text { Akhir }\end{array}$ & REM & REM & REM & FEM \\
\hline
\end{tabular}

Sumber: Data Diolah (2019).

Berdasarkan hasil Uji Wald dan Uji Hausman terhadap model pengaruh dana perimbangan terhadap pertumbuhan ekonomi di keempat kluster pada Tabel 3, menunjukkan bahwa untuk keempat kluster yang ada kluster I, II dan III menggunakan REM sedangkan untuk kluster IV menggunakan model regresi panel FEM. Berdasarkan hasil tersebut maka langkah selanjutnya adalah dilakukan regresi panel data berdasarkan hasil tabel 3 di atas. Hasil analisa regresi panel data terhadap model pengaruh dana perimbangan terhadap kemandirian keuangan daerah dapat dilihat pada Tabel 4 di bawah.

Tabel 4. Hasil Estimasi Model Pengaruh Dana Perimbangan terhadap Kemandirian Keuangan Daerah pada Masing-Maing Kluster

\begin{tabular}{|c|c|c|c|c|}
\hline Variabel & $\begin{array}{c}\text { Kluster } \\
\text { I } \\
\text { (REM) }\end{array}$ & $\begin{array}{c}\text { Kluster } \\
\text { II } \\
\text { (REM) }\end{array}$ & $\begin{array}{c}\text { Kluster } \\
\text { III } \\
\text { (REM) }\end{array}$ & $\begin{array}{c}\text { Kluster } \\
\text { IV } \\
\text { (FEM) }\end{array}$ \\
\hline Konstanta & 7.503 & 4.811 & 34.738 & 25.729 \\
\hline $\begin{array}{c}\text { Dana } \\
\text { Perimbangan }\end{array}$ & 0.837 & $0.224^{* *}$ & 0.184 & 0.860 \\
\hline $\begin{array}{c}\text { Jumlah } \\
\text { Penduduk }\end{array}$ & $0.726^{* *}$ & 0.153 & 0.154 & 0.006 \\
\hline $\begin{array}{c}\text { Pertumbuhan } \\
\text { Ekonomi }\end{array}$ & $0.335^{*}$ & $0.325^{* * *}$ & $0.179^{* *}$ & $0.182^{* *}$ \\
\hline $\begin{array}{c}\text { Tingkat } \\
\text { Pengangguran }\end{array}$ & 0.027 & 0.153 & 0.035 & 0.218 \\
\hline SDM & 0.436 & $0.200^{*}$ & 0.212 & 0.007 \\
\hline R-Square & 0.4944 & 0.557 & 0.739 & 0.787 \\
\hline Adj. ${ }^{2}$ & 0.4731 & 0.513 & 0.724 & 0.742 \\
\hline Prob F-Stat & 0.000 & 0.000 & 0.000 & 0.000 \\
\hline
\end{tabular}

*signifikan pada $\alpha 10 \%$;

**signifikan pada $\alpha 5 \%$;

*** signifikan pada $\alpha 1 \%$

Sumber : Data Diolah (2019).

Berdasarkan Tabel 4 menunjukkan hasil pengelolahan regresi panel data didapatkan bahwa variabel dana perimbangan memiliki pengaruh yang positif dan signifikan terhadap kemandirian keuangan daerah hanya pada kluster II. Hal ini berarti bahwa setiap kenaikan dana perimbangan untuk pemerintah daerah di Kluster II dapat mendorong kemandirian keuangan daerah, 
sedangkan untuk kluster lainnya memiliki pengaruh yang positif akan tetapi tidak signifikan terhadap kemandirian keuangan daerah.

Lebih lanjut berdasarkan hasil analisis regresi panel data yang terdapat pada Tabel $4 \mathrm{di}$ atas, variabel jumlah penduduk memiliki pengaruh positif dan signifikan terhadap kemandirian keuangan hanya untuk kluster I, sementara kluster lainnya tidak signifikan mempengaruh kemandirian keuangan daerah. Variabel pertumbuhan ekonomi berpengaruh positif dan signifikan terhadap kemandirian keuangan daerah pada kluster I, II, III dan IV. Sedangkan variabel SDM tidak signifikan mempengaruhi kemandirian keuangan pemerintah daerah.

\subsection{Analisa Metode Kuadran Pengaruh Dana Perimbangan terhadap Kemandirian Keuangan Daerah}

Dari hasil regresi panel data terhadap model pengaruh dana perimbangan terhadap kemandirian keuangan daerah, maka langkah selanjutnya adalah menyandingkan dan memetakan ke dalam analisis metode kuadran yang akan membagi menjadi empat kuadran. Metode kuadran tersebut akan memetakan masing-masing kluster ke dalam 4 kuadran. Kuadran tersebut dengan rincian berikut:

\subsubsection{Analisis Metode Kuadran Kluster I}

Hasil analisis kuadran untuk Kluster I tersebut dapat dilihat pada Gambar 3 berikut di bawah:

1. Menurut analisa kuadran didapatkan hasil bahwa tidak terdapat kabupaten/kota yang terdapat di kuadran I. Artinya tidak ada kabupaten/kota yang diberikan dana perimbangan yang tinggi atau besar akan tetapi memiliki kemandirian keuangan daerah yang tinggi di Kluster I.

2. Berdasarkan mapping analisa kuadran didapatkan hasil bahwa kabupaten/kota yang terdapat di kuadran II yaitu kabupaten/kota terdapat Kabupaten Sleman, Kabupaten Bantul, Kabupaten Aceh Utara, Kabupaten Gunung Kidul, Kabupaten Merauke, dan Kabupaten Mimika. Kuadran II ini menunjukkan kabupaten/kota yang memiliki dana perimbangan yang besar akan tetapi kemandirian keuangan yang rendah.

3. Berdasarkan mapping analisa kuadran didapatkan hasil bahwa kabupaten/kota yang berada di kuadran III adalah Kabupaten Puncak Jaya dan Kota Yogyakarta. Hasil ini menunjukan bahwa Kabupaten Puncak Jaya dan Kota Yogyakarta merupakan daerah dengan dana perimbangan rendah namun memiliki kemandirian keuangan yang relatif tinggi.

4. Menurut analisa kuadran didapatkan hasil bahwa kabupaten/kota yang terdapat di kuadran IV yaitu kabupaten/kota lainnya yang tidak terdapat di kuadran I, II dan III, seperti contohnya Kota Banda Aceh, Kota Sorong, dan kabupaten serta kota lainnya. Dapat disimpulkan bahwa hampir 88,6 persen lebih kabupaten/kota yang ada di Kluster I masuk ke dalam kuardran IV, artinya dalam bahasa lain hampir 88,6 persen lebih kabupaten/kota mendapatkan dana perimbangan dengan kemandirian keuangan daerah yang relatif rendah

Gambar 3. Analisa Kuadran Dana Perimbangan dan Kemandirian Keuangan Daerah Kluster I

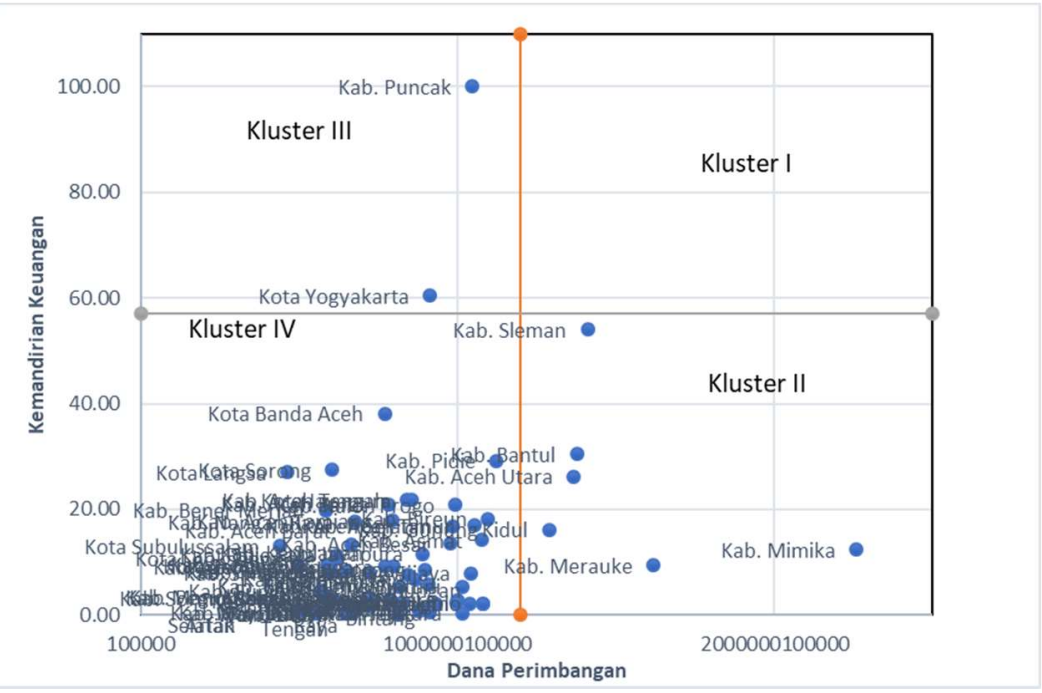

Sumber : Data Diolah (2019). 


\subsubsection{Analisis Metode Kuadran Kluster II}

Hasil analisis kuadran untuk Kluster II tersebut dapat dilihat pada Gambar 4 berikut di bawah:

1. Berdasarkan mapping analisa kuadran didapatkan hasil bahwa kabupaten/kota yang berada di kuadran I ini adalah Kota Surabaya, Kota Bekasi, Kabupaten Tanggerang, dan Kota Bandung. Hasil ini menunjukkan bahwa daerah tersebut memiliki dana perimbangan yang relatif besar dengan tingkat kemandirian yang juga besar.

2. Menurut analisa kuadran didapatkan hasil bahwa kabupaten/kota yang terdapat di kuadran II yaitu Kota Tanggerang, Kota Semarang, Kota Medan, Kota Makasar, Kota Bandar Lampung, Kabupaten Karawang, dan Kota Palembang. Hasil ini menunjukkan bahwa daerah ini merupakan daerah dengan dana perimbangan yang relatif tinggi namun tingkat kemandirian keuangan yang relatif rendah.
3. Hasil analisa kuadran didapatkan hasil bahwa kabupaten/kota yang berada di kuadran III adalah Kota Batu, Kabupaten Hulu Sungai Tengah, Kabupaten Hulu Sungai Selatan, Kota Tabalong, Kota Batam dan Kota Tanggerang. Hasil pada kuadran III menunjukkan bahwa kabupaten/kota memiliki dana perimbangan yang relatif kecil namun memiliki kemandirian keuangan yang tinggi.

4. Berdasarkan mapping analisa kuadran didapatkan hasil bahwa kabupaten/kota yang terdapat di kuadran IV yaitu kabupaten/kota lainnya yang tidak terdapat di kuadran I, II dan III, seperti contohnya Kota Depok, Kabupaten Bandung, Kota Denpasar dan kabupaten serta kota lainnya. Dapat disimpulkan bahwa hampir 28 persen lebih kabupaten/kota yang ada di Kluster II masuk ke dalam kuardran IV, artinya dalam bahasa lain hampir 28 persen lebih kabupaten/kota mendapatkan dana perimbangan dengan kemandirian keuangan yang relatif rendah

Gambar 4. Analisa Kuadran Dana Perimbangan dan Kemandirian Keuangan Daerah di Kluster II

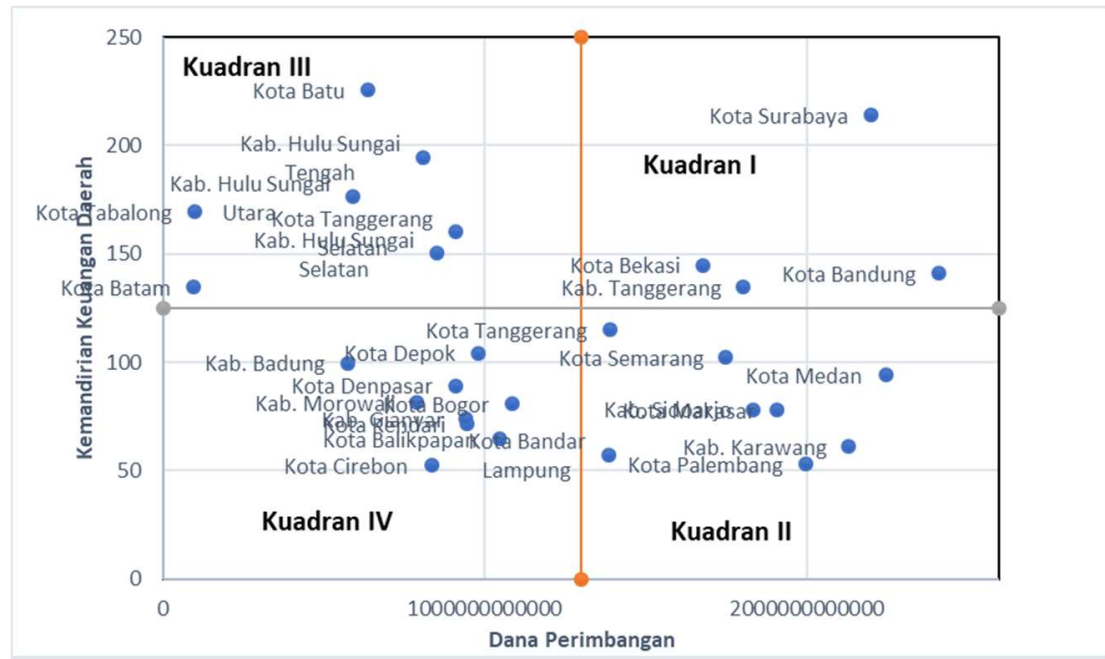

Sumber : Data Diola (2019).

\subsubsection{Analisis Metode Kuadran Kluster III}

Hasil analisis kuadran untuk Kluster III tersebut dapat dilihat pada Gambar 5. Berikut di bawah:

1. Menurut analisa kuadran didapatkan hasil bahwa tidak ada kabupaten/kota yang berada di kuadran I.

2. Berdasarkan analisa kuadran didapatkan hasil bahwa kabupaten/kota yang terdapat di kuadran II yaitu Kabupaten Bandung, Kabupaten Deli Serdang, Kabupaten Cianjur, Kabupaten Simalungun. Hasil ini menunjukkan bahwa daerah tersebut memiliki dana perimbangan yang tinggi namun tingkat kemandirian keuangan daerah yang relatif rendah
3. Menurut analisa kuadran didapatkan hasil bahwa tidak ada kabupaten/kota yang berada di kuadran III.

4. Berdasarkan mapping analisa kuadran didapatkan hasil bahwa kabupaten/kota yang terdapat di kuadran IV yaitu Kota Pekan Baru, Kota Pontianak, dan kabupaten serta kota lainnya. Dapat disimpulkan bahwa hampir 88 persen lebih kabupaten/kota yang ada di Kluster II masuk ke dalam kuardran IV, artinya dalam bahasa lain hampir 88 persen lebih kabupaten/kota mendapatkan dana perimbangan dengan kemandirian keuangan yang relatif rendah. 
Gambar 5 Analisa Kuadran Dana Perimbangan dan Kemandirian Keuangan Daerah di Kluster III

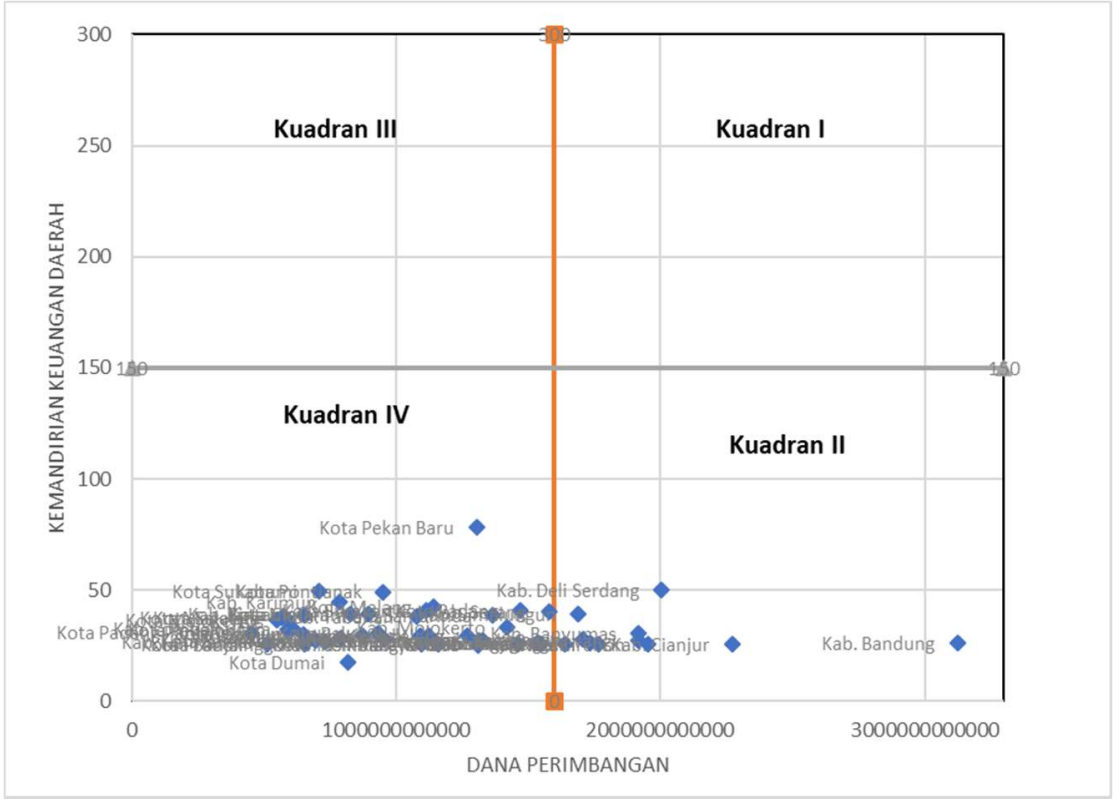

Sumber: Data Diolah (2019).

\subsubsection{Analisa Metode Kuadran Kluster IV}

Hasil analisis kuadran untuk Kluster IV tersebut dapat dilihat pada Gambar 6. berikut di bawah :

1. Menurut analisa kuadran didapatkan hasil bahwa tidak ada kabupaten/kota yang berada di kuadran I.

2. Hasil analisa kuadran didapatkan hasil bahwa tidak ada kabupaten/kota yang berada di kuadran II.

3. Berdasarkan mapping analisa kuadran didapatkan hasil bahwa yang berada di kuadran III yaitu Kabupaten Takalar, Kabupaten Barito Selatan, dan Kabupaten Karimun. Hasil ini menunjukkan bahwa daerah tersebut memiliki dana perimbangan yang rendah namun memiliki kemandirian keuangan yang relatif tinggi.

4. Hasil kuadran didapatkan hasil bahwa kabupaten/kota yang terdapat di kuadran IV adalah sisanya kabupaten/kota yang tidak berada di kuadran I, II dan III yaitu, Kabupaten Maluku, Kabupaten Pasuruan, Kota Pangkal Pinang dan kabupaten serta kota lainnya. Dapat disimpulkan bahwa hampir 98,8 persen lebih kabupaten/kota yang ada di Kluster II masuk ke dalam kuardran IV, artinya dalam bahasa lain hampir 98,8 persen lebih kabupaten/kota mendapatkan dana perimbangan dengan kemandirian keuangan yang relatif rendah.

Gambar 6. Analisa Kuadran Dana Perimbangan dan Kemandirian Keuangan Daerah di Kluster IV

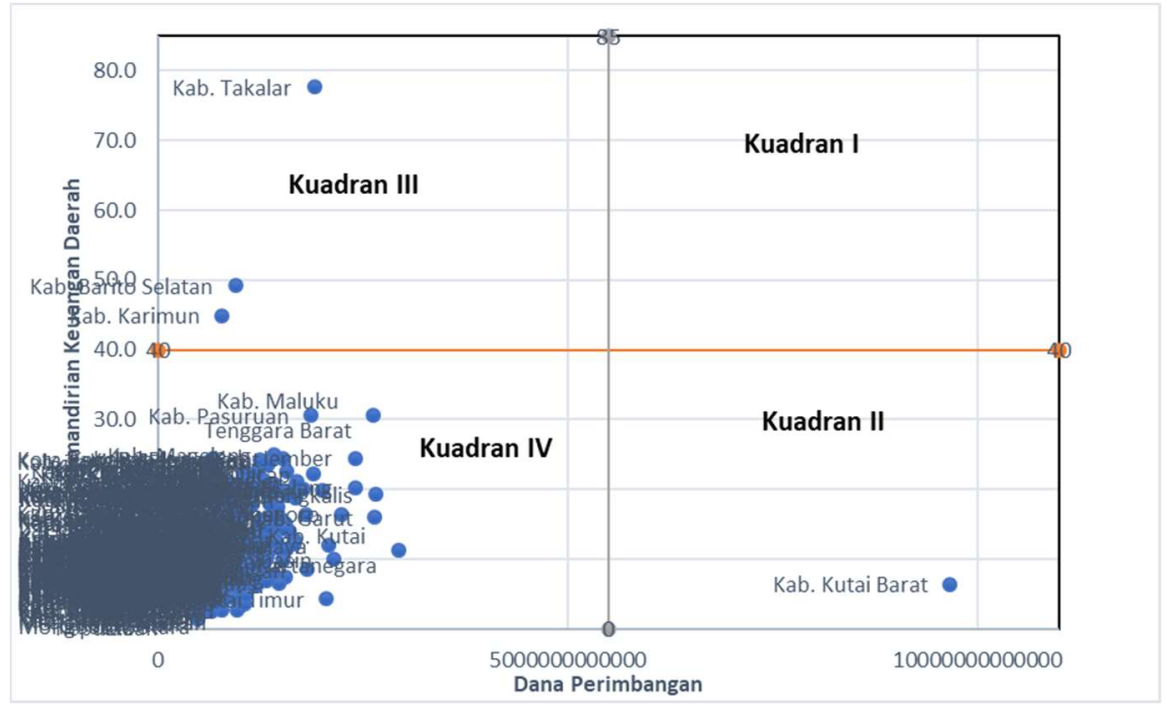

Sumber : Data Diolah (2019). 
Hasil analisa regresi panel yang telah diuraikan pada bagian sebelumnya didapatkan hasil bahwa dana perimbangan memiliki pengaruh yang positif dan signifikan terhadap kemandirian keuangan daerah hanya untuk kabupaten/kota yang berada di kluster II, sedangkan untuk kabupaten/kota yang berada di kluster I, III dan IV tidak memiliki pengaruh yang signifkan terhadap kemandirian keuangan daerah. Hasil regresi panel ini terhadap data yang ada sejalan dengan hasil analisa kuadran yang juga telah dilakukan pada bagian sebelumnya, kurang lebih 91,3 persen kabupaten kota yang berada di kluster I, III dan IV berada pada kuadran IV, yaitu kabupaten/kota memiliki dana perimbangan yang rendah dengan kemandirian keuangan yang juga relatif rendah. Hasil analisa kuadran untuk kabupaten/kota di kluster II, menunjukkan bahwa menunjukkan sebaran yang merata dengan konsentralisasi di kuadran III.

Hasil penelitian ini, ditemukan bahwa dana perimbangan tidak memiliki pengaruh terhadap kemandirian keuangan untuk kabupaten/kota di kluster 1, 3 dan 4 sejalan dengan penelitian yang dilakukan oleh Stone (2015), yang melakukan penelitian mengenai pengaruh dana perimbangan terhadap kondisi keuangan atau kemandirian keuangan dari pemerintah. Hasil penelitian tersebut menemukan bahwa tidak terdapat pengaruh antara fiscal decentralization terhadap kondisi keuangan pemerintah. Sedangkan hasil penelitian untuk kabupaten/kota di kluster 2 yang memiliki pengaruh signifikan terhadap kemandirian keuangan sejalan dengan penelitian yang dilakukan oleh Sulistyo (2017).

Terkait dengan kondisi keuangan dan kemandirian keuangan pemerintah daerah, Clark (2015) menjelaskan bahwa pemerintah daerah seharusnya wajib untuk melakukan evaluasi terhadap kondisi keuangan kesehatan pemerintah daerah secara periodik. Hal senada dikemukakan oleh Rivenbark dan Allison (2010) yang menekankan bahwa pemerintah daerah harus mengetahui secara akurat kondisi keuangan di masing-masing daerah. Hal ini menjadi penting bagi daerah untuk dapat melakukan evaluasi kondisi keuangan di pemerintah daerah untuk dapat meningkatkan kemampuan daerah untuk membuat keputusan kebijakan tentang penganggaran di daerah.

Evaluasi terhadap pelaksanaan otonomi daerah dan desentralisasi di Indonesia yang telah berlaku selama 22 tahun, ditemukan bahwa tidak semua daerah dapat menjalankan pemerintahan secara mandiri. Masih banyak daerah-daerah yang sangat menggantungkan diri dari dana perimbangan yang ditransfer dari Pemerintah Pusat kepada pemerintah daerah sebagai sandaran utamanya. Wakil Presiden Jusuf Kalla mengatakan setiap pemberian kewenangan harus dibarengi dengan kewajiban. Fenomena yang terjadi saat ini, dimana sebagian daerah masih menggantungkan diri kepada transfer dari Pemerintah Pusat harus ada perubahan secara mendasar. Hal ini dikarenakan dengan komposisi seperti saat ini, dimana banyak daerah menggantungkan diri terhadap dana perimbangan dan masih banyak yang belum mendiri seharusnya ada komitmen dari pemerintah daerah yang lebih kuat untuk menggunakan anggaran yang ada demi kemandirian keuangan daerah (Hidayat, 2018).

Masing bergantungnya daerah kepada dana perimbangan ditunjukkan dengan rendahnya rasio kemandirian keuangan daerah. Menurut Savitry, Saleh, dan Arifin (2011) rendahnya rasio kemandirian keuangan daerah dikarenakan beberapa hal, diantaranya adalah sumber penerimaan daerah dan dasar pengenaan biaya tampaknya pendapatan asli daerah masih belum bisa diandalkan bagi daerah untuk otonomi daerah, rendahnya basis pajak atau retribusi yang ada di daerah dan kurang dapatnya pemerintah daerah menggali sumber-sumber pendapatan asli daerah. Hal ini diperparah dengan sumber-sumber potensial untuk menambah pendapatan asli daerah masih banyak dikuasai oleh Pemerintah Pusat, sedangkan untuk basis pajak masih dikelola oleh Pemerintah Pusat.

Lebih lanjut ada beberapa sumber penyebab redahnya kemandirian daerah menurut Muhammad (2016) yaitu (1) rendahnya potensi pendapatan asli daerah yang bersangkutan; dan (2) beban belanja APBD yang relatif besar di era desentralisasi fiskal. Itulah mengapa pengelolaan belanja APBD dalam pemerintahan daerah menjadi harus lebih rasional dan bersifat investasi produktif yang seharusnya menjadi aspek utama dalam mendorong kemandirian keuangan bagi pemerintah daerah (Dwi, 2013). Perubahan pola pengelolaan APBD yang lebih rasional dan bersifat investasi produktif dalam mendorong kemandirian keuangan daerah merupakan hal yang mutlak harus dilakukan pemerintah daerah khususnya kepada pemerintahan daerah yang memiliki tingkat kemandirian keuangan rendah dan pertumbuhan ekonomi yang juga masih rendah (Haryanto, 2017).

Namun pada sisi lain, rendahnya kemandirian keuangan pemerintah daerah juga disebabkan oleh kapasitas sumber daya manusia yang dimiliki oleh pemerintah daerah. Banyak pemerintah daerah memiliki kapasitas SDM yang rendah, dampaknya adalah minimnya terobosan dan kreativitas aparat pelaksana dalam mencari sumber-sumber pembiayaan baru bagi peningkatan pendapatan asli daerah. Di sisi lain kontribusi laba yang disetorkan oleh Badan Usaha Milik Daerah (BUMD) di banyak pemerintah 
daerah juga belum dapat diharapkan sebagai sumber peningkatan pendapatan asli daerah. Hal ini dikarenakan laba yang dihasilkan oleh BUMD per tahun masih relatif rendah (Risyanto, 2015).

Keterbatasan dan keluasan pemerintah daerah kabupaten/kota untuk menarik pajak dan retribusi juga menjadi masalah bagi peningkatan PAD daerah (Hamzah, 2008). Batasan-batasan yang ditelah ditetapkan oleh Pemerintah Pusat dalam bentuk regulasi harusnya ditinjau kembali demi peningkatan PAD kabupaten/kota.

\section{KESIMPULAN DAN SARAN}

Hasil penelitian ini menemukan bahwa variabel dana perimbangan tidak memiiki pengaruh yang signifikan pada kabupaten/kota di Kluster I, III dan IV terhadap kemandirian keuangan daerah. Sementara itu untuk kabupaten/kota di Kluster II variabel dana perimbangan memiliki pengaruh yang signifikan terhadap kemandirian keuangan daerah.

Hasil penelitian ini sejalan dengan mapping yang telah dilakukan, ditemukan bahwa berdasarkan data yang ada, kabupaten/kota di kluster I, III dan IV ternyata kurang lebih 91,3 persen kabupaten/kota berada di kuadran IV yang berarti kabupaten/kota memiliki dana perimbangan yang relatif rendah dan kemandirian keuangan yang juga rendah. Sedangkan untuk mapping kabupaten/kota di kluster II banyak tersebar di kuadran II sampai dengan IV.

Hasil penelitian ini menemukan masih banyak kabupaten/kota yang belum dapat menjalankan pemerintahan secara mandiri dalam konteks kemandirian keuangan derah. Hal ini berarti masih banyak kabupaten/kota yang bergantung sangat terhadap dana perimbangan. Ketergantungan akan dana perimbangan ini harus dapat dicarikan solusi dengan cara kabupaten/kota harus dapat mengalokasikan anggaran dalam APBD kepada potensi-potensi yang dapat dijadikan sebagai sumber penerimaan bagi daerah khususnya alokasi belanja APBD kepada investasi yang bersifat rasional dan produktif.

\section{IMPLIKASI DAN KETERBATASAN}

Penelitian ini diharapkan memberikan manfaat dan masukan baik sebagai referensi akademis maupun dalam tataran praktis para pengambil kebijakan terkait pelaksanaan desentralisasi fiskal dan otonomi di Indonesia. Pelaksanaan otonomi dan desentralisasi fiskal yang berjalan selama kurang lebih hampir 22 tahun di Indonesia memiliki beberapa tujuan utama, diantaranya adalah mendorong pertumbuhan ekonomi daerah, meningkatkan kemampuan dan kemandirian daerah. Hasil akhir yang diharapkan adalah terciptanya kemandirian keuangan daerah yang berdaulat dan mandiri secara finansial, sehingga hasil akhirnya adalah terciptanya masyarakat yang lebih sejahtera.

Penelitian ini juga masih jauh dari kata sempurna dan masih memiliki kekurangan. Oleh karena itu, penelitian selanjutnya terkait pengaruh dana perimbangan terhadap kemandirian keuangan daerah dapat dikembangkan dengan lebih baik dari sisi akademis maupun praktis bagi para pengambil kebijakan terkait desentralisasi dan otonomi di Indonesia. Sehingga penelitian pengaruh dana perimbangan terhadap kemandirian keuangan daerah dapat lebih komprehensif dan lebih bermanfaat lebih luas baik bagi akademisi maupun praktisi.

\section{PENGHARGAAN (ACKNOWLEDGEMENT)}

Selama penyusunan penelitian ini, Penulis menerima banyak bantuan baik berupa sumbangan pemikiran maupun tenaga dari berbagai pihak. Untuk itu penulis tidak lupa mengucapkan terimakasih kepada:

1. Dr. Indra Pahlevi, selaku Kepala Pusat Penelitian, Setjen dan Badan Keahlian DPR RI yang telah memberikan dukungan dan izin kepada penulis untuk melanjutkan pendidikan Doktoral dan melakukan penelitian ini.

2. Dr. Rahaju Setya Wardani, selaku Kepala Pusat Pendidikan dan Pelatihan, Setjen dan Badan Keahlian DPR RI yang telah memberikan dukungan dan izin kepada penulis untuk melanjutkan pendidikan Doktoral dan melakukan penelitian ini.

3. Para promotor, Prof. Muhammad Zilal dan Co Promotor, Dr. Eleonora Solfida yang tiada lelah memberikan masukan dan arahan terhadap penyelesaian penelitian ini.

Selanjutnya atas segala hal yang tertuang dalam hasil penelitian ini termasuk atas kesalahan yang terjadi didalamnya, sepenuhnya menjadi tanggung jawab Penulis.

\section{REFERENSI}

Clark, B. Y. (2015). Evaluating the validity and reliability of the financial condition index at the local level. Public Budgeting \& Finance, Summer, 66-88.

Diaz-Serrano, L., \& Rodríguez-Pose, A. (2015). Decentralization and the welfare state: what do citizens perceive? social indicators research, 120(2), 411-435. https://doi.org/ 


\subsection{7/s11205-014-0599-5}

Dwi, S. (2013). Pengaruh penganggaran terhadap kinerja aparat pemda melalui sistem informasi keuangan daerah (studi kasus: Pemda Kabupaten Kudus). Jurnal Ekonomi Dan Bisnis, 12(01).

Dwipayana, A. S. E. (2003). Membangun good governance di desa. Yogyakarta: Insitute of Research and Emporwerment.

Ekananda, M. (2016). Analisis ekonometrika data panel teori dan pembahasan menyeluruh bagi penelitian ekonomi, bisnis dan sosial. Jakarta: Mitra Wacana Media.

Fafurida, F., \& Pratiwi, E. N. (2017). Financial independence of regencies and cities in Central Java. Economic Journal of Emerging Markets, 9(2), 199-209. https://doi.org/10.20885/ejem.vol9.iss2.art 9

Gao, Song; Meng, Xiangyi; Zhang, L. (2014). Fiscal decentralization and life satisfaction: evidence from urban China. Social Indicators Research, 119(3), 1177-1194.

Ghuman, B. S., \& Singh, R. (2013). Decentralization and delivery of public services in Asia. Policy and Society, 32(1), 7-21. https://doi.org/10.1016/j.polsoc.2013.02.0 01

Ginting, A. M. (2018). Desentralisasi fiskal dan kemandirian keuangan daerah: studi kasus di Kabupaten/Kota Provinsi Sumatera Utara. In Desentralisasi Fiskal dan Persaingan Usaha (pp. 126-194). Jakarta: Pusat Penelitian Badan Keahlian DPR RI dan Inteligensia Intrans Pusblisihing.

Halim, A. (2004). Akuntansi keuangan daerah. Jakarta: Salemba Empat.

Hamzah, Z. (2008). Kajian teoritis desentralisasi fiskal (first). Jakarta: Institute of Publishing, Indonesia Business School.

Hankla, C. R., \& Hankla, C. R. (2009). When is fiscal decentralization good for governance? when is fiscal decentralization good for governance? Publius, 39(4), 632-650. https://doi.org/10.1093/publius/pjn034

Haryanto, J. T. (2015). Desentralisasi fiskal seutuhnya. Diakses 12 Januari 2019 dari http://kemenkeu.go.id/Artikel/desentralisa si-fiskal-seutuhnya

Haryanto, J. T. (2017). Penghasil SDA dan non-SDA di era desentralisasi fiskal (Comparative analysis of regional financial mapping from the producer of natural resources and nonnatural resources in the fiscal decentralization era). Jurnal Ekonomi dan Kebijakan Publik, 8(2), 103-116.

Haryanto, J. T. (2018). Regional financial performance evaluation in the Indonesian fiscal decentralization era. Jurnal Perspektif Pembiayaan Dan Pembangunan Daerah, 5(3), 115-128.

Hidayat, A. R. (2018). Otonomi Daerah kemandirian daerah belum terwujud. Kompas, p. 2.

Undang-Undang Nomor 23 Tahun 2014 tentang Pemerintah Daerah. Indonesia: Republik Indonesia.

Jin, J., \& Zou, H. F. (2005). Fiscal decentralization, revenue and expenditure assignments, and growth in China. Journal of Asian Economics, 16(6), 1047-1064. https://doi.org/10.1016/ j.asieco.2005.10.006

Kalirajan, K. (2012). Fiscal decentralization and development outcomes in India: An Exploratory Analysis. World Development, 40(8), 1511-1521. https://doi.org/10.1016/ j.worlddev.2012.04.005

Khamdana, A. (2016). Pengaruh desentralisasi fiskal terhadap pertumbuhan ekonomi daerah di Indonesia, 2008-2012. Indonesia Treasury Review, 1(1), 23-38.

Kuncoro. (2014). Otonomi daerah. Jakarta: Erlangga.

Malik, S, Mahmood-Ul-Hassan \& Husain, S. (2006). Fiscal decentalization and economic growth in Pakistan. The Pakistan Development Review, 45(4), 845-854.

Mardiasmo. (2002). Otonomi dan manajemen keuangan daerah. Yogyakarta: Andi

Michael, H. M. (2008). The tiebout hypothesis 50 years later: lessons and lingering challenges for metropolitan governance in the 21st century. Public Administration Review, 68(1), 97-109. Diakses dari http://dx.doi.org/ 10.1111/j.1540-6210.2007.00840.x

Muhammad, H. (2016). Analisis kemampuan keuangan kabupaten/kota di Provinsi Sumatera Barat. Jurnal Sungkai, 4(2).

Oates, W. (1972). Fiscal federalims. New York: Harcourt Brace.

Psycharis, Y., Zoi, M., \& Iliopoulou, S. (2015). Decentralization and local government fiscal autonomy: evidence from the Greek municipalities. Environment and Planning C: Government and Policy, 34(2), 262-280. https://doi.org/10.1177/0263774X156141 53 
Risyanto, H. (2015). Analisis kemampuan keuangan daerah dan kemandirian keuangan daerah serta pengaruhnya terhadap pertumbuhan ekonomi Kabupaten Garut. Coopetition, 6(1), 21-33.

Rivenbark, W. C., Roenigk, D. J., \& Allison, G. S. (2010). Conceptualizing financial condition in local government. Journal of Public Budgeting, Accounting and Financial Management, 22(2), 149-177.

Savitry, E., Saleh, H. A., \& Arifin, I. (2011). Analisis kemampuan keuangan daerah dalam pelaksanaan otonomi daerah di Kota Surakarta. Skripsi. Government: Jurnal Ilmu Pemerintahan, 4, 23-34.

Simanjuntak, T. H \& Mukhlis, I. (2016). The relation of fiscal decentralization, regional finance and social justice for the local development of Indonesia. Applied Economics and Finance, $4(1)$. https://doi.org/10.11114/aef.v4i1.1911

Solihin, A., \& Lesatri, N. A. (2010). Analisis ketimpangan fiskal di Indonesia sebelum dan sesudah otonomi daerah dan. Majalah Ekonomi, (1), 20-35.

Stone, S. B. (2015). The effect of fiscal decentralization on the financial condition of municipal government. International Journal of Public Administration, 38(6), 453-460. https://doi.org/10.1080/01900692.2014.94 9740

Sulistyo, A. T. (2017). Analisis kinerja keuangan pemerintah Provinsi Kalimantan Timur. Indonesia Treasury Review, 3(1), 43-59.

Suprantiningrum, S. R. (2015). Analisis kinerja pengelolaan keuangan daerah dan tingkat kemandirian daerah di era otonomi daerah (Studi Kasus Kota Semarang Tahun 20092013). Media Ekonomi Dan Manajemen, 30(1), 30-40. https://doi.org/10.24856/mem.v30i1.232

Wasistiono, Sadu \& Polyando, P. (2017). Politik desentralisasi di Indonesia. Sumedang: Institut Pemerintahan Dalam Negeri (IPDN) Press Jatinangor. 
Lampiran I :

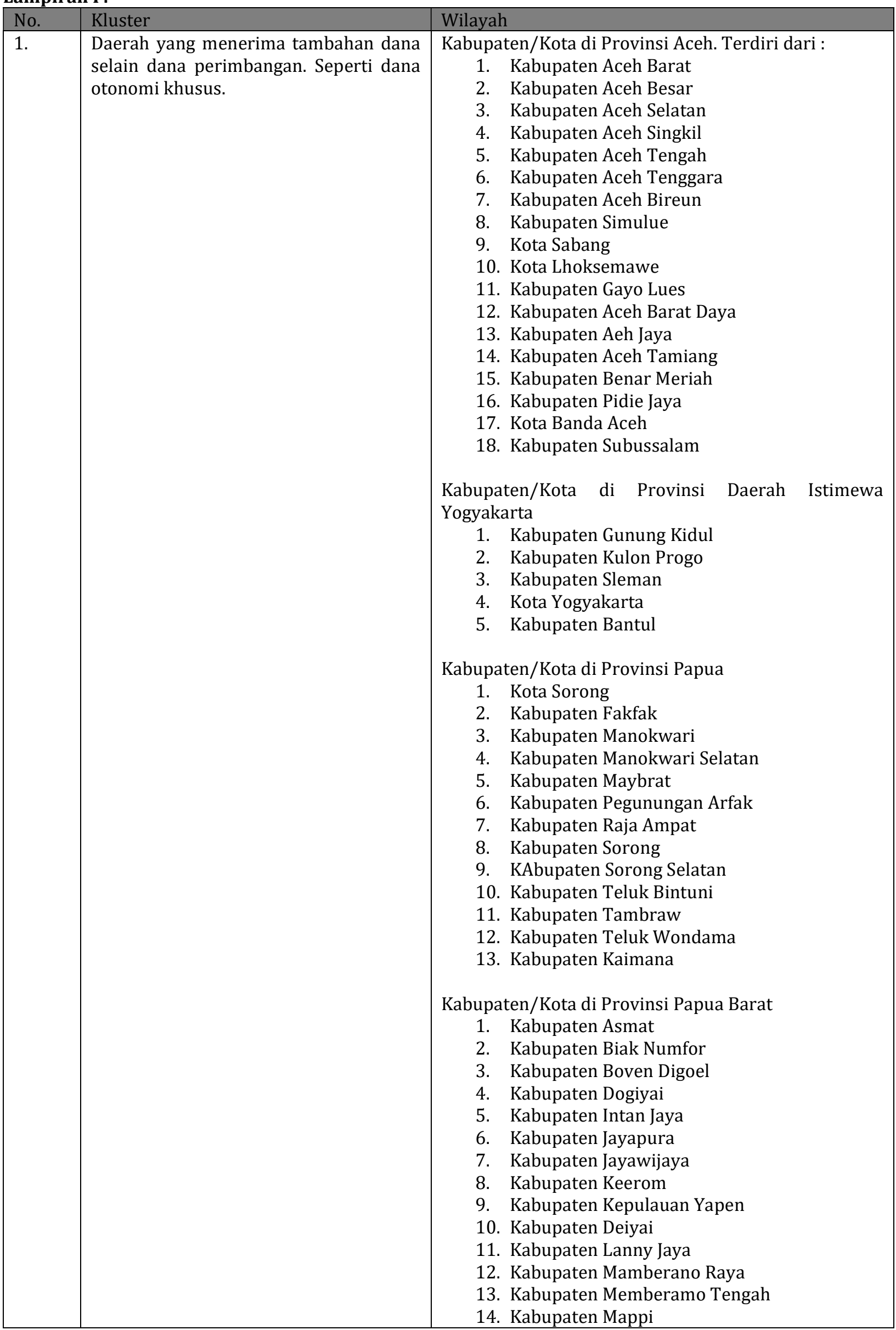




\begin{tabular}{|c|c|c|}
\hline No. & Kluster & Wilayah \\
\hline & & $\begin{array}{l}\text { 15. Kabupaten Merauke } \\
\text { 16. Kabupaten Mimika } \\
\text { 17. Kabupaten Nabire } \\
\text { 18. Kabupaten Nduga } \\
\text { 19. Kabupaten Paniai } \\
\text { 20. Kabupaten Pengunungan Bintang } \\
\text { 21. Kabupaten Puncak } \\
\text { 22. Kabupaten Puncak Jaya } \\
\text { 23. Kabupaten Sarmi } \\
\text { 24. Kabupaten Supiori } \\
\text { 25. Kabupaten Tolikara } \\
\text { 26. Kabupaten Waropen } \\
\text { 27. Kabupaten Yahukimo } \\
\text { 28. Kabupaten Yalimo } \\
\text { 29. Kota Jayapura }\end{array}$ \\
\hline 2. & $\begin{array}{llr}\text { Daerah yang memiliki } & \text { proporsi } \\
\text { pendapatan asli } & \text { daerah } & \text { (PAD) } \\
\text { dibandingkan } & \text { dengan } & \text { dana } \\
\text { perimbangan }>50 \% & & \end{array}$ & $\begin{array}{l}\text { 1. Kota Medan } \\
\text { 2. Kota Palembang } \\
\text { 3. Kota Bandar Lampung } \\
\text { 4. Kabupaten Karawang } \\
\text { 5. Kota Bandung } \\
\text { 6. Kota Bekasi } \\
\text { 7. Kota Bogor } \\
\text { 8. Kota Cirebon } \\
\text { 9. Kota Depok } \\
\text { 10. Kota Semarang } \\
\text { 11. Kabupaten Sidoarjo } \\
\text { 12. Kota Surabaya } \\
\text { 13. Kota Balikpapan } \\
\text { 14. Kabupaten Morowali } \\
\text { 15. Kota Makasar } \\
\text { 16. Kota Kendari } \\
\text { 17. Kabupaten Badung } \\
\text { 18. Kabupaten Gianyar } \\
\text { 19. Kota Denpasar } \\
\text { 20. Kabupaten Tangerang } \\
\text { 21. Kota Tangerang } \\
\text { 22. Kota Tangerang Selatan } \\
\text { 23. Kota Batam }\end{array}$ \\
\hline 3. & 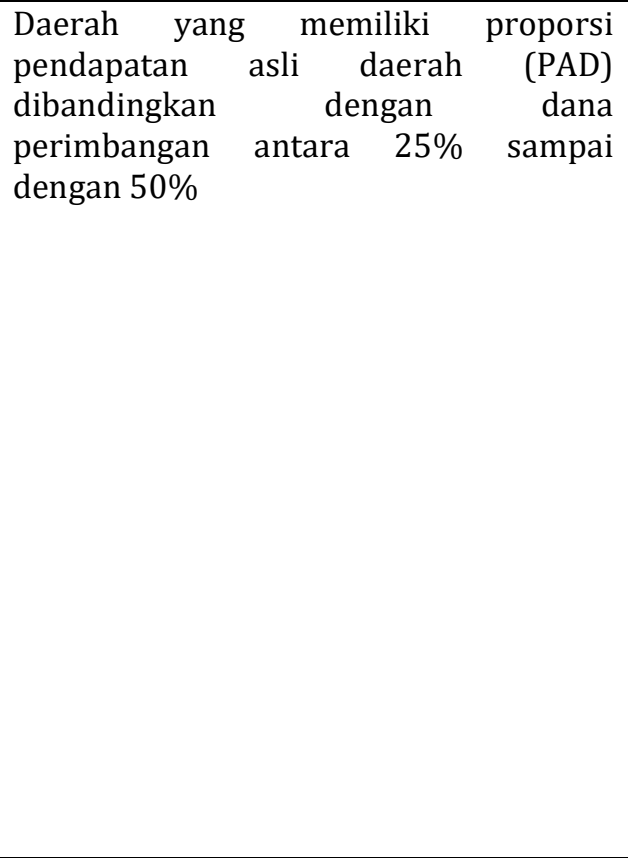 & $\begin{array}{l}\text { 1. Kabupaten Deli Serdang } \\
\text { 2. Kabupaten Simalungun } \\
\text { 3. Kota Padang Panjang } \\
\text { 4. Kota Padang } \\
\text { 5. Kota Dumai } \\
\text { 6. Kota Pekan Baru } \\
\text { 7. Kota Jambi } \\
\text { 8. Kabupaten Bandung } \\
\text { 9. Kabupaten Cianjur } \\
\text { 10. Kabupaten Cirebon } \\
\text { 11. Kabupaten Majalengka } \\
\text { 12. Kabupaten Sumedang } \\
\text { 13. Kota Sukabumi } \\
\text { 14. Kota Tasikmalaya } \\
\text { 15. Kota Cimahi } \\
\text { 16. Kota Banjar } \\
\text { 17. Kabupaten Banyumas } \\
\text { 18. Kabupaten Kendal } \\
\text { 19. Kabupaten Kudus } \\
\text { 20. Kabupaten Pekalongan } \\
\text { 21. Kabupaten Purworejo }\end{array}$ \\
\hline
\end{tabular}




\begin{tabular}{|c|c|c|}
\hline No. & Kluster & Wilayah \\
\hline & & $\begin{array}{l}\text { 22. Kabupaten Rembang } \\
\text { 23. Kabupaten Semarang } \\
\text { 24. Kabupaten Tegal } \\
\text { 25. Kota Magelang } \\
\text { 26. Kota Pekalongan } \\
\text { 27. Kota Salatiga } \\
\text { 28. Kota Surakarta } \\
\text { 29. Kabupaten Banyuwangi } \\
\text { 30. Kabupaten Jombang } \\
\text { 31. Kabupaten Kediri } \\
\text { 32. Kabupaten Lamongan } \\
\text { 33. Kabupaten Mojokerto } \\
\text { 34. Kota Kediri } \\
\text { 35. Kota Malang } \\
\text { 36. Kota Madiun } \\
\text { 37. Kota Mojokerto } \\
\text { 38. Kota Probolinggo } \\
\text { 39. Kabupten Jombang } \\
\text { 40. Kabupaten Tuban } \\
\text { 41. Kota Surabaya } \\
\text { 42. Kota Pontianak } \\
\text { 43. Kota Banjarbaru } \\
\text { 44. Kota Samarinda } \\
\text { 45. Kota Palu } \\
\text { 46. Kota Luwu Timur } \\
\text { 47. Kabupaten Buleleng } \\
\text { 48. Kabupaten Tabanan } \\
\text { 49. Kabupaten Lombok Barat } \\
\text { 50. Kota Mataram } \\
\text { 51. Kabupaten Lombok Utara } \\
\text { 52. Kabupaten Halmahera Utara } \\
\text { 53. Kabupaten Serang } \\
\text { 54. Kabupaten Karimun } \\
\text { 55. Kabuapten Bintan } \\
\text { 35ala }\end{array}$ \\
\hline 4. & $\begin{array}{lcr}\text { Daerah yang memiliki } & \text { proporsi } \\
\text { pendapatan asli } & \text { daerah } & \text { (PAD) } \\
\text { dibandingkan } & \text { dengan } & \text { dana } \\
\text { perimbangan kurang dari } 25 \% & \end{array}$ & $\begin{array}{l}\text { 1. Kabupaten Asahan } \\
\text { 2. Kabupaten Dairi } \\
\text { 3. Kabupaten Karo } \\
\text { 4. Kabupaten Labuhan Batu } \\
\text { 5. Kabupaten Langkat } \\
\text { 6. Kabupaten Mandailing Natal } \\
\text { 7. Kabupaten Nias } \\
\text { 8. Kabupaten Tapanuli Selatan } \\
\text { 9. Kabupaten Tapanuli Tengah } \\
\text { 10. Kabupaten Tapanuli Utara } \\
\text { 11. Kabupaten Toba Samosir } \\
\text { 12. Kota Binjai } \\
\text { 13. Kota Pematang Siantar } \\
\text { 14. Kota Sibolga } \\
\text { 15. Kota Tanjung Balai } \\
\text { 16. Kota Tebing tinggi } \\
\text { 17. Kota Padangsidimpuan } \\
\text { 18. Kabupaten Pakpak Barat } \\
\text { 19. Kabupaten Nias Selatan } \\
\text { 20. Kabupaten Humbang Hasudutan } \\
\text { 21. Kabupaten Sedang Berdagai } \\
\text { 22. Kabupaten Samosir } \\
\text { 23. Kabupaten Batubara } \\
\text { 24. Kabupaten Padang Lawas } \\
\text { 25. Kabupaten Padang Lawas Utara }\end{array}$ \\
\hline
\end{tabular}




\begin{tabular}{|c|c|c|}
\hline No. & Kluster & Wilayah \\
\hline & & $\begin{array}{l}\text { 26. Kabupaten Labuhanbatu Selatan } \\
\text { 27. Kabupaten Labuhanbatu Utara } \\
\text { 28. Kabupaten Nias Utara } \\
\text { 29. Kabupaten Nias Barat } \\
\text { 30. Kota Gunung Sitoli } \\
\text { 31. Kabupaten Lima Puluh Kota } \\
\text { 32. Kabupaten Agam } \\
\text { 33. Kabupaten Kepulauan Mentawai } \\
\text { 34. Kabupaten Padang Pariaman } \\
\text { 35. Kabupaten Pasaman } \\
\text { 36. Kabupaten Pesisir Selatan } \\
\text { 37. Kabupaten Siunjung } \\
\text { 38. Kabupaten Solok } \\
\text { 39. Kabupaten Tanah Datar } \\
\text { 40. Kota Bukit Tinggi } \\
\text { 41. Kota Payakumbuh } \\
\text { 42. Kota Sawahlunto } \\
\text { 43. Kota Solok } \\
\text { 44. Kota Pariman } \\
\text { 45. Kabupaten Pasaman Barat } \\
\text { 46. Kabupaten Dharmasraya } \\
\text { 47. Kota Solok Selatan } \\
\text { 48. Kabupaten Bengkalis } \\
\text { 49. Kabupaten Indragiri Hilir } \\
\text { 50. Kabupaten Indragiri Hulu } \\
\text { 51. Kabupaten Kampar } \\
\text { 52. Kabupaten Kuantan Singigi } \\
\text { 53. Kabupaten Pelawan } \\
\text { 54. Kabupaten Rokan Hilir } \\
\text { 55. Kabupaten Rokan Hulu } \\
\text { 56. Kabupaten Siak } \\
\text { 57. Kabupaten Kepulauan Meranti } \\
\text { 58. Kabupaten Batanghari } \\
\text { 59. Kabupaten Bungo } \\
\text { 60. Kabupaten Kerinci } \\
\text { 78. Kab. Kabupaten Lubuk Linggau } \\
\text { 76. Kabupaten Merangin } \\
\text { 79. Kabupaten Ogan Komering Ulu Selatan } \\
\text { 62. Kabupaten Muaro Jambi } \\
\text { 73. Kabupaten Banyuasin } \\
\text { 73. Kabupaten Sarolangun } \\
\text { 61. Kabupaten Penukal Abab Lematang Ilir } \\
\text { 62. Kabupaten Tanjung Jabung Barat } \\
\text { 65. Kabupaten Tanjung Jabung Timur } \\
\text { 66. Kabapaten Tebo } \\
\text { 67. Kabupaten Lahat } \\
\text { 63. Kabupaten Musi Banyuasin } \\
\text { 84. Kabupaten Bengkulu Utara }\end{array}$ \\
\hline
\end{tabular}




\begin{tabular}{|c|c|c|c|}
\hline No. & Kluster & \multicolumn{2}{|l|}{ Wilayah } \\
\hline & & 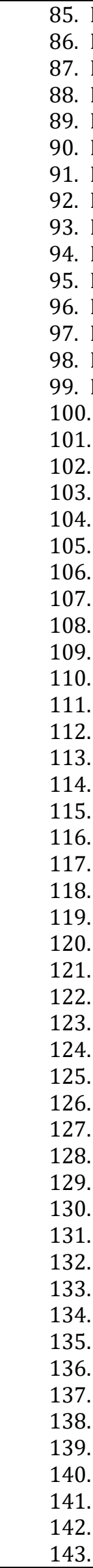 & 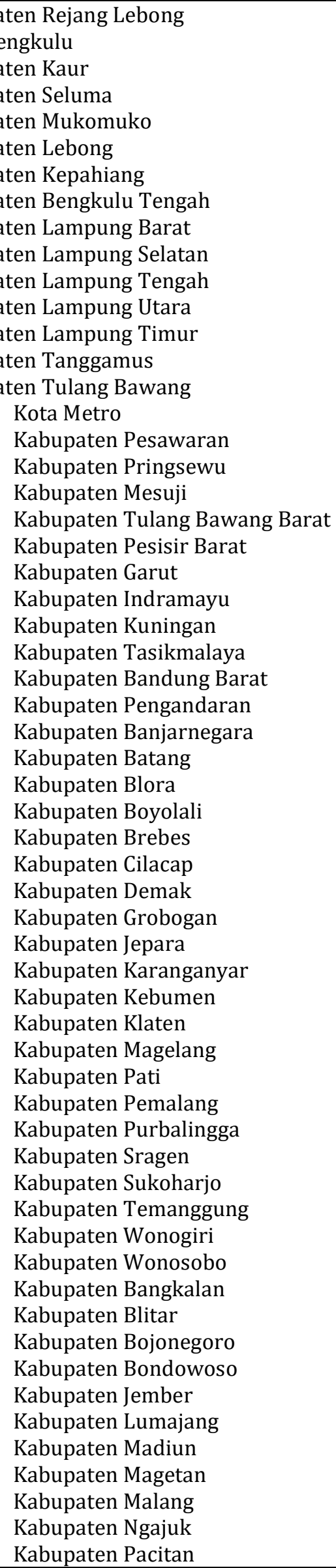 \\
\hline
\end{tabular}




\begin{tabular}{|c|c|c|c|}
\hline No. & Kluster & Wilayah & \\
\hline & & 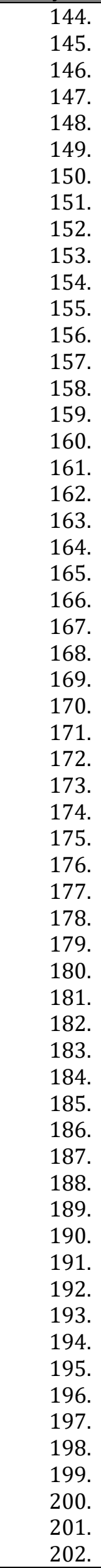 & 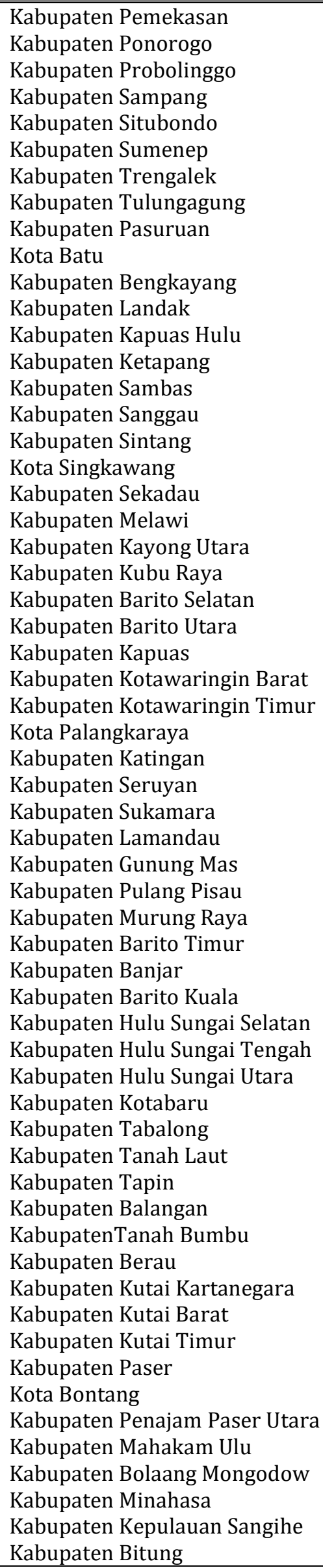 \\
\hline
\end{tabular}




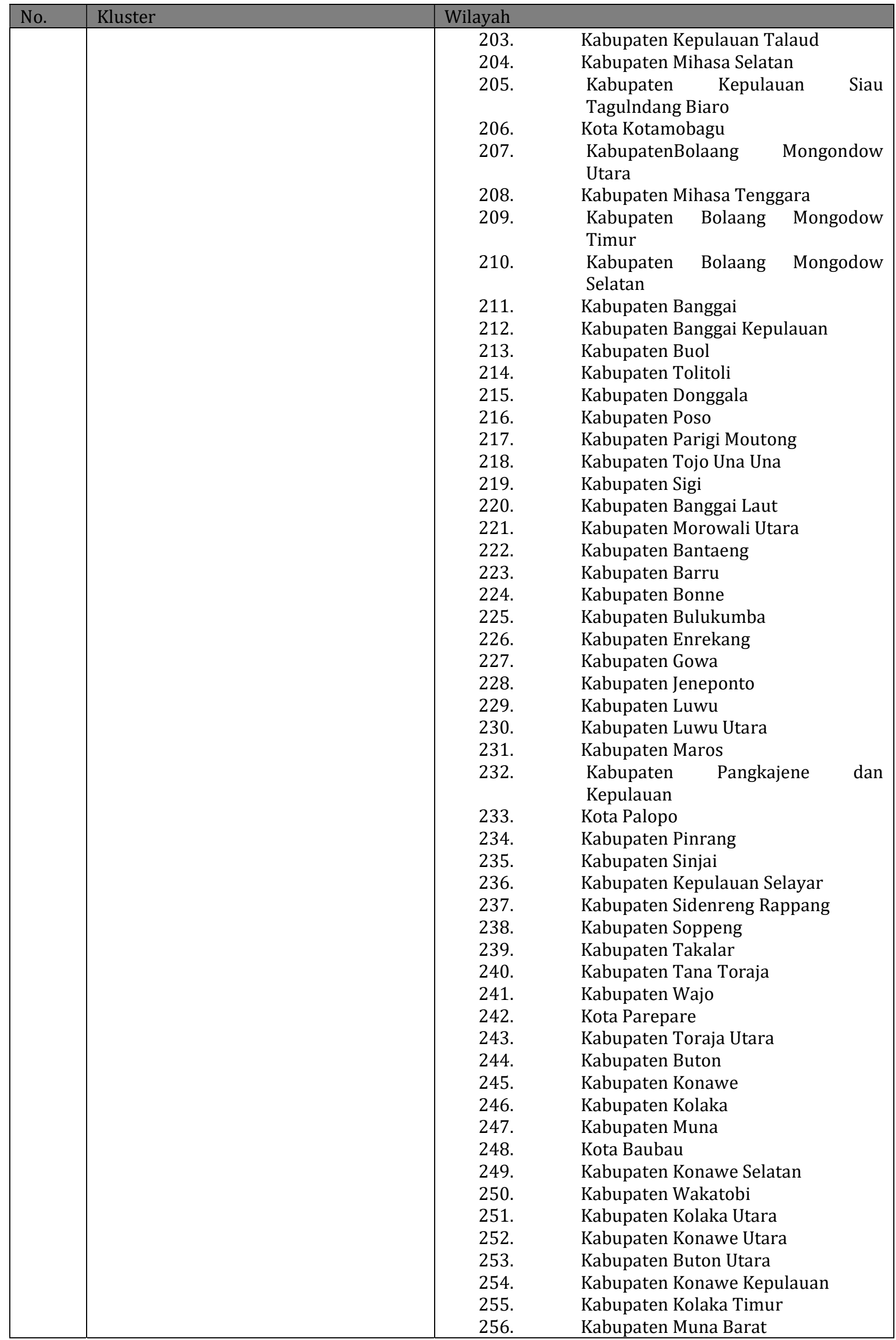




\begin{tabular}{|c|c|c|c|}
\hline \multirow[t]{60}{*}{ No. } & Kluster & Wilayah & \\
\hline & & 257. & Kabupaten Buton Tengah \\
\hline & & 258. & Kabupaten Buton Selatan \\
\hline & & 259. & Kabupaten Bangli \\
\hline & & 260. & Kabupaten Jembarana \\
\hline & & 261. & Kabupaten Klungkung \\
\hline & & 262. & Kabupaten Bima \\
\hline & & 263. & Kabupaten Dompu \\
\hline & & 264. & Kabupaten Lombok Tengah \\
\hline & & 265. & Kabupaten Lombok Timur \\
\hline & & 266. & Kabupaten Sumbawa \\
\hline & & 267. & Kabupaten Alor \\
\hline & & 268. & Kabupaten Belu \\
\hline & & 269. & Kabupaten Ende \\
\hline & & 270. & Kabupaten Flores Timur \\
\hline & & 271. & Kabupaten Kupang \\
\hline & & 272. & Kabupaten Lembata \\
\hline & & 273. & Kabupaten Manggarai \\
\hline & & 274. & Kabupaten Ngada \\
\hline & & 275. & Kabupaten Sikka \\
\hline & & 276. & Kabupaten Sumba Barat \\
\hline & & 277. & Kabupaten Sumba Timur \\
\hline & & 278. & Kabupaten Timor Tengah Selatan \\
\hline & & 279. & Kabupaten Timor Tengah Utara \\
\hline & & 280. & Kota Kupang \\
\hline & & 281. & Kabupaten Rote Ndao \\
\hline & & 282. & Kabupaten Manggarai Barat \\
\hline & & 283. & Kabupaten Nagekeo \\
\hline & & 284. & Kabupaten Sumba Barat Daya \\
\hline & & 285. & Kabupaten Sumba Tengah \\
\hline & & 286. & Kabupaten Manggarai Timur \\
\hline & & 287. & Kabupaten Sabu Rijua \\
\hline & & 288. & Kabupaten Malaka \\
\hline & & 289. & Kabupaten Maluku Tenggara Barat \\
\hline & & 290. & Kabupaten Maluku Tengah \\
\hline & & 291. & Kabupaten Maluku Tenggara \\
\hline & & 292. & Kabupaten Buru \\
\hline & & 293. & Kota Ambon \\
\hline & & 294. & Kabupaten Seram Bagian Barat \\
\hline & & 295. & Kabupaten Seram Bagian Timur \\
\hline & & 296. & Kabupaten Kepulauan Aru \\
\hline & & 297. & Kota Tual \\
\hline & & 298. & Kabupaten Maluku Barat Daya \\
\hline & & 299. & Kabupaten Buru Selatan \\
\hline & & 300. & Kabupaten Biak Numfor \\
\hline & & 301. & Kabupaten Halmahera Tengah \\
\hline & & 302. & Kota Ternate \\
\hline & & 303. & Kabupaten Halmahera Barat \\
\hline & & 304. & Kabupaten Halmahera Timur \\
\hline & & 305. & Kabupaten Hamahera Selatan \\
\hline & & 306. & Kabupaten Kepulauan Sula \\
\hline & & 307. & Kota Tidore Kepulauan \\
\hline & & 308. & Kabupaten Pulau Morotai \\
\hline & & 309. & Kabupaten Pulau Taliabu \\
\hline & & 310. & Kabupaten Lebak \\
\hline & & 311. & Kabupaten Pandeglang \\
\hline & & 312. & Kabupaten Bangka \\
\hline & & 313. & Kabupaten Belitung \\
\hline & & 314. & Kota Pangkal Pinang \\
\hline & & 315. & Kabupaten Bangka Selatan \\
\hline
\end{tabular}




\begin{tabular}{|c|c|c|c|}
\hline No. & Kluster & Wilayah & \\
\hline & & $\begin{array}{l}316 . \\
317 . \\
318 . \\
319 . \\
320 . \\
321 . \\
322 . \\
323 . \\
324 . \\
325 . \\
326 . \\
327 . \\
328 . \\
329 . \\
330 . \\
331 . \\
332 . \\
333 . \\
334 . \\
335 . \\
336 . \\
337 . \\
338 . \\
339 .\end{array}$ & $\begin{array}{l}\text { Kabupaten Bangka Tengah } \\
\text { Kabupaten Bangka Barat } \\
\text { Kabupaten Belitung Timur } \\
\text { Kabupaten Boalemo } \\
\text { Kabupaten Gorontalo } \\
\text { Kabupaten Puhuwato } \\
\text { Kabupaten Bone Bolango } \\
\text { Kabupaten Gorontalo Utara } \\
\text { Kabupaten Natuna } \\
\text { Kabupaten Kepulauan Anambas } \\
\text { Kabupaten Karimun } \\
\text { Kabupaten Tanjung Pinang } \\
\text { Kabupaten Lingga } \\
\text { Kabupaten Majene } \\
\text { Kabupaten Mamuju } \\
\text { Kabupaten Polewali Mandar } \\
\text { Kabupaten Mamasa } \\
\text { Kabupaten Mamuju Utara } \\
\text { Kabupaten Mamuju Tengah } \\
\text { Kabupaten Bulungan } \\
\text { Kabupaten Malinau } \\
\text { Kabupaten Nunukan } \\
\text { Kota Tarakan } \\
\text { Kabupaten Tana Tidung }\end{array}$ \\
\hline
\end{tabular}

